\title{
Dune Volume Changes at Decadal Timescales and Its Relation with Potential Aeolian Transport
}

\author{
Glenn Strypsteen ${ }^{1, * \mathbb{D}}$, Rik Houthuys ${ }^{2}$ and Pieter Rauwoens ${ }^{1}$ \\ 1 Construction TC, Dept. of Civil Engineering, Bruges Campus, KU Leuven, Spoorwegstraat 12, \\ B-8200 Bruges, Belgium; pieter.rauwoens@kuleuven.be \\ 2 Geoconsultant, Suikerkaai 8, B-1500 Halle, Belgium; rik.houthuys@telenet.be \\ * Correspondence: glenn.strypsteen@kuleuven.be
}

Received: 11 September 2019; Accepted: 7 October 2019; Published: 8 October 2019

check for updates

\begin{abstract}
Long-term changes in dune volume at the Belgian coast are analyzed based on measured data by airborne surveys available from 1979. For most of the $65 \mathrm{~km}$ long coastal stretch, dune volume increases linearly in time at a constant rate. Dune growth varies between $0-12.3 \mathrm{~m}^{3} / \mathrm{m} / \mathrm{year}$ with an average dune growth of $6.2 \mathrm{~m}^{3} / \mathrm{m} /$ year, featuring large variations in longshore directions. Based on a wind data set from 2000-2017, it is found that potential aeolian sediment transport has its main drift from the west to southwest direction (onshore to oblique onshore). Based on a modified Bagnold model, onshore potential aeolian sediment transport ranges to a maximum of $9 \mathrm{~m}^{3} / \mathrm{m} /$ year, while longshore potential aeolian sediment transport could reach up to $20 \mathrm{~m}^{3} / \mathrm{m} /$ year. We found an important correlation between observed and predicted dune development at decadal timescales when zones with dune management activities are excluded. Most of the predicted data are within a factor of two of the measured values. The variability in potential transport is well related to the variability in dune volume changes at the considered spatial-temporal scale, suggesting that natural dune growth is primarily caused by aeolian sediment transport from the beach. It also suggests that annual differences in forcing and transport limiting conditions (wind and moisture) only have a modest effect on the overall variability of dune volume trends.
\end{abstract}

Keywords: aeolian sediment transport; dune development; Belgian coast; decadal timescales; annual timescales

\section{Introduction}

Coastal dunes provide safety against flooding during storm events. They also have functions for recreation and nature conservation. Compared to hard engineering structures like sea dykes, coastal dunes are in favor because they are primarily being built by natural aeolian processes [1-3]. However, natural coastal dunes are dynamic features and the disadvantage, therefore, is that the provided safety level is variable in time [4]. Long-term coastal dune development is a net result of combined storm wave erosive and aeolian processes. It is the net result which determines if the dunes are eroding or growing. Predicting and evaluating these processes is a prerequisite for many management activities. In the past few decades, a lot of research has been carried out on dune erosion which can be simulated with good accuracy. Yet, predictions on aeolian sediment transport from the beach towards the dunes, leading to dune recovery, are still difficult to make [5-8]. This study examines how annual to decadal variations in wind climate (indirect potential aeolian transport) correlate with annual to decadal variations in dune volume along the Belgian coast. Decadal variations are of interest because they describe the general coastline development.

Coastal dune development studies generally focus on the measurement of short-term transport processes in the timescale of hours to days [9-13]. Sometimes, at these timescales, a one to one relation 
is found between predicted and observed values [14]. Coastal dune development is also frequently studied by the measurement of long-term topographical elevation variations in the timescale of months to years $[8,10,15-17]$. Primarily, these topographical elevation changes are related to calculated potential transport rates [18]. Long-term aeolian sediment transport from the beach towards coastal dunes is generally predicted by integrating hourly meteorological data, such as wind speed and direction from standard meteorological stations, into sediment transport equations (e.g., [19-23]). Unfortunately, at these timescales, the calculated potential sediment input in the dunes from the beach frequently do not agree with volume observations in the dunes (e.g., [10,15]). Keijsers et al. [18] and de Vries et al. [4] studied aeolian transport and dune behavior on annual to decadal timescales and found no significant correlation. Both found greater correlation between dune behavior and erosive events by storms. Though, for their study at the Dutch coast, Keijsers et al. [18] found stronger correlations between a time series of potential sediment transport and dune volume on wider beaches $(>200 \mathrm{~m})$. This suggests potentially stronger correlations at the Belgian coast, where beach widths are generally wider (between $150 \mathrm{~m}$ and $400 \mathrm{~m}$ ). The wider beaches at the Belgian coast are primarily created by massive sand nourishments to cope with future flooding risks and hazards. Especially since the 1990s, nourishments are used to keep the sediment budgets along the coast positive. The nourished sand is naturally distributed in the coastal zone.

When coastal dune development and its relation with potential aeolian sediment transport is studied on decadal timescales, the effects of erosive and accretive years should eventually average out. Annual differences would then be observed as small perturbations on the trend at decadal timescales. Potential transport should then, hypothetically, be well related to dune behavior at the considered spatial-temporal scale. This would suggest that dune growth (at locations not suffering too much from dune erosion) is primarily caused by aeolian sediment transport from the beach.

The purpose of this paper is:

1. To gain insight into long-term dune development at the Belgian coast. This study is based on the analysis of airborne photogrammetric and airborne laser scanner (LiDAR) data of the dunes from 1979-2018.

2. To gain insight into annual potential aeolian sediment transport quantities and how it behaves on decadal timescales (long-term). Annual potential aeolian sediment transport along the Belgian coastline is estimated by the use of a modified Bagnold model, which has been validated by short-term field data of aeolian sediment transport rates [14], applied to a wind data set from 2000-2017.

3. To gain insight into the correlation between observed and predicted dune volume on an annual timescale. Year-to-year variations (between elevation measurements) in potential transport and dune volume changes are compared.

4. To gain insight into the correlation between observed and predicted dune volume on decadal timescales. Trend analysis on predicted and measured dune volume is conducted for comparisons on a decadal timescale.

5. To explain longshore variations of the correlations by distinguishing between 'natural' and 'managed' beach sections of the Belgian coast featuring dunes.

\section{Regional Setting}

Located between France and the Netherlands (Figure 1), the modest $65 \mathrm{~km}$ long Belgian coast was historically characterized by sandy beaches, backed by wide sand dunes, mudflats and tidal marshes [24]. However, over the last 50 years, these marshes and mudflats were modified by draining and diking them to develop agriculture, habitation and major economical recreation [25]. Nowadays, like many coastal areas worldwide, the Belgian coast faces increasing challenges due to coastal erosion, sea-level rise, and an increased risk of flooding. 


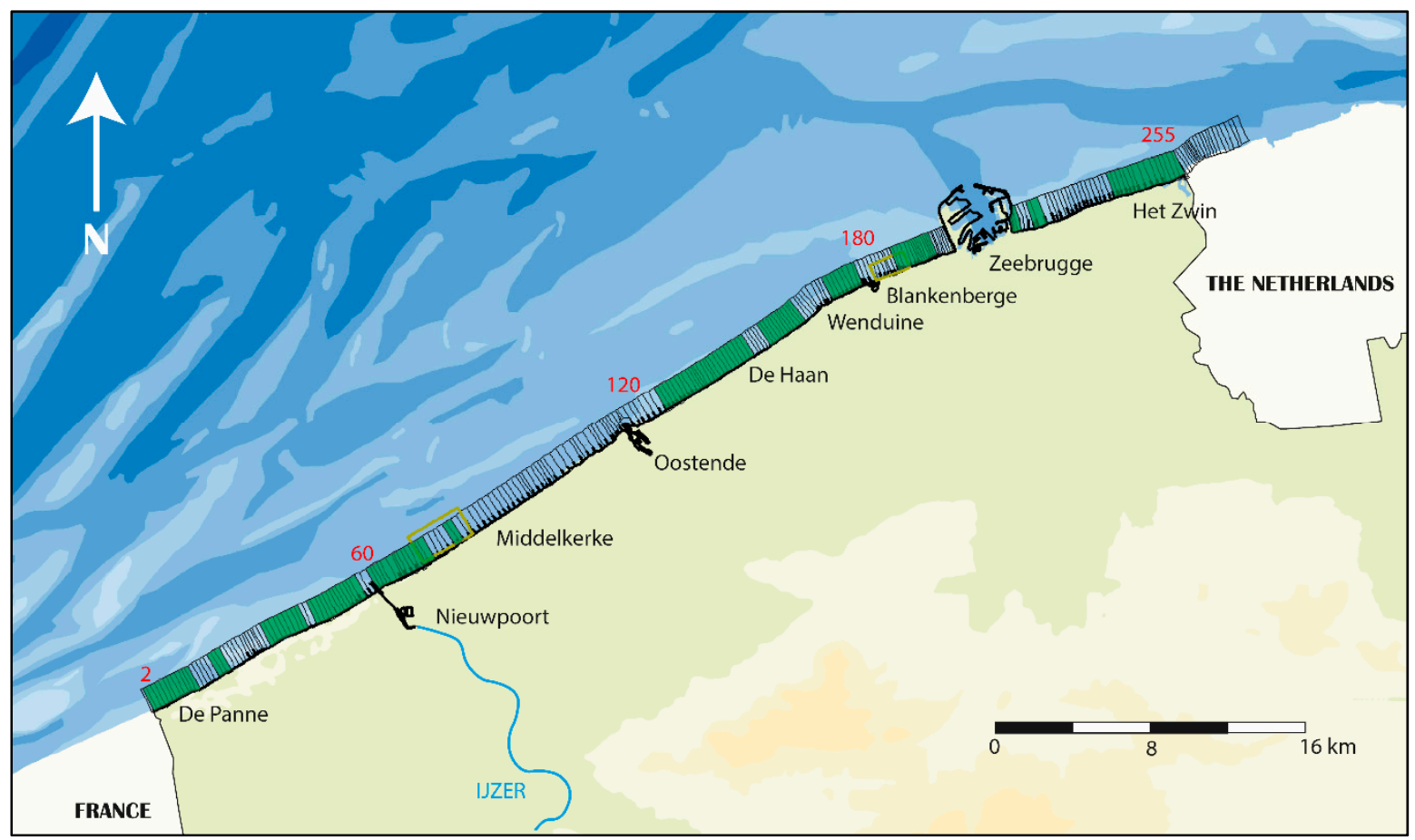

Figure 1. The $65 \mathrm{~km}$ long Belgian coast is located at the North Sea, between the French and the Dutch border and is divided into 254 coastal sections. The river 'IJzer' flows into the North Sea at Nieuwpoort. The green areas indicate the locations with vegetated coastal dunes.

The Belgian coast is southwest-northeast orientated with a mean of $62^{\circ}$ to the north (Figure 2). Local variations from the mean coastal orientation are found, especially around the harbor mouths (Ostend $(30 \mathrm{~km})$ and Zeebrugge $(50 \mathrm{~km}))$, and the nature reserve 'het Zwin', on the border with the Netherlands.

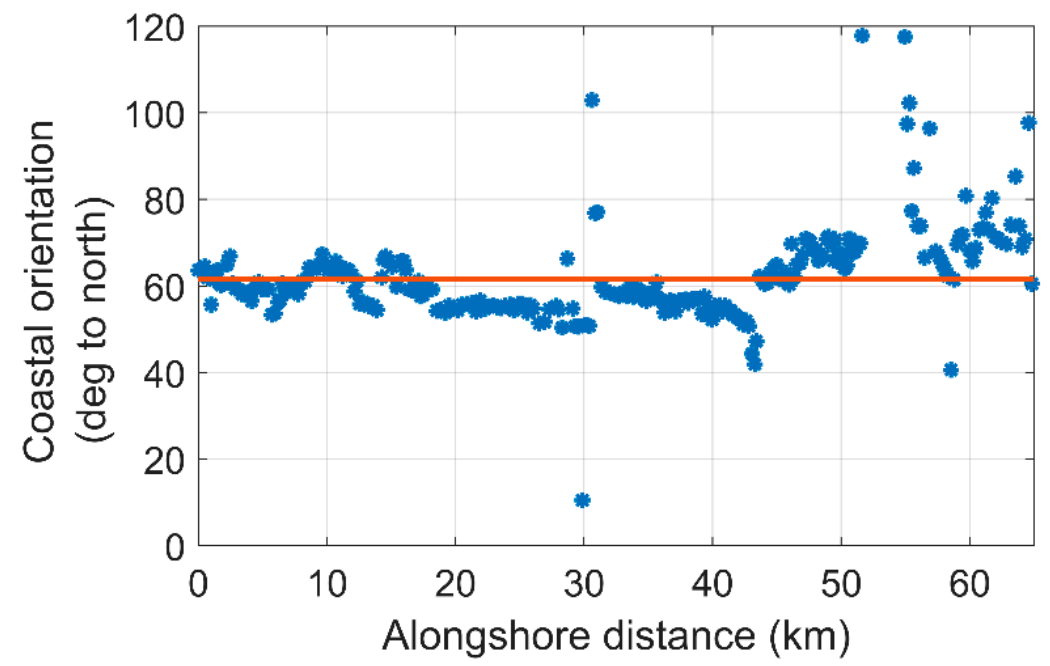

Figure 2. Coastal orientation of the Belgian coast. It represents the orientation of dunes or dykes. The mean coastal orientation is $62^{\circ}$ with respect to the north (red line).

The Belgian coast consists of sandy beaches, which are generally up to $400 \mathrm{~m}$ wide in the southwest and only $150 \mathrm{~m}$ in the northeast (Figure 3). Beach width is defined here as the horizontal distance 
between mean low-water level $\left(+1.39 \mathrm{~m} \mathrm{TAW}^{1}\right)$ and dune foot $(+6.89 \mathrm{~m} \mathrm{TAW})$. During springtide, beach width can range from $100 \mathrm{~m}$ to $600 \mathrm{~m}$ [26]. The upper beach width, defined as the horizontal distance between mean high-water level (+4.39 m TAW) and dune foot (+6.89 m TAW), ranges from $30 \mathrm{~m}$ to $100 \mathrm{~m}$. The beaches along the entire coastline are very gently sloping, although the slope increases from west to east (Figure 3). Due to the construction of the jetties (approximately $3 \mathrm{~km}$ in length) of Zeebrugge harbor (between $52-55 \mathrm{~km}$ alongshore), the beach width is relatively large, causing a very mild beach slope in that region.
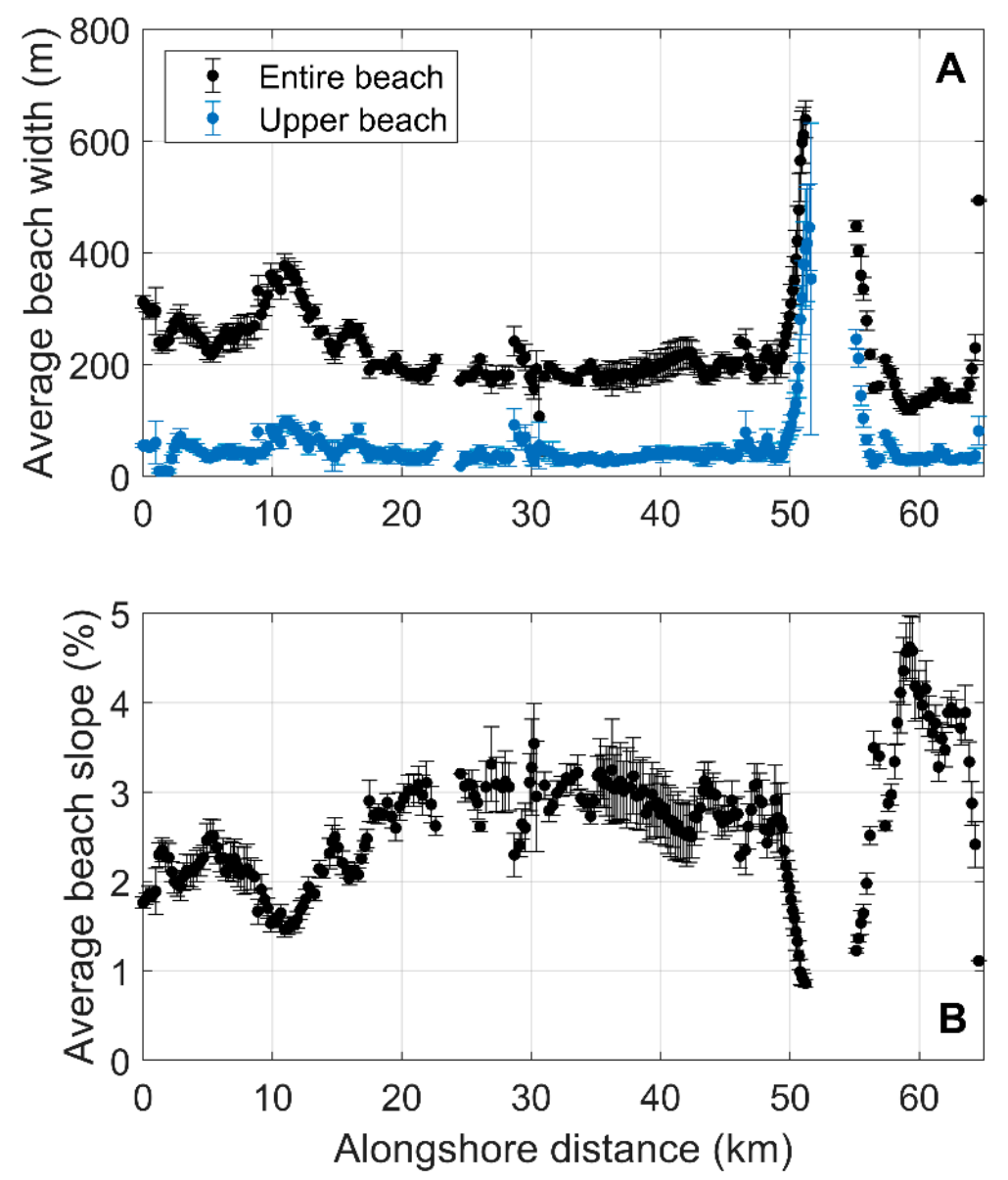

Figure 3. (A) Average beach width along the Belgian coast based on airborne surveys from 2000-2017. Beach width is the horizontal distance between the average low-water level and the dune foot. Upper beach width is the horizontal distance between the average high-water level and the dune foot or a hard defense structure. (B) Average beach slope along the Belgian coast based on airborne surveys from 2000-2017. Error bars indicate the standard deviation.

Due to a natural gradient and an increase in nourishments towards the northeast, the sand becomes gradually coarser along the coast, from $150 \mu \mathrm{m}$ in the west to up to $400 \mu \mathrm{m}$ in the east [24]. Figure 4 shows the mean grain size variation along the Belgian coast. It is from a unique data set from the year 2000 that covers the entire Belgian coast [27]. Three to four samples were taken at the surface on the upper beach, and were analyzed for grain size after removal of organic material. On the basis of the available measurement data, the coast is divided into zones, in which the nature of the beach sand is assumed to be homogeneous. In total, 16 zones are distinguished. The black line represents the 16

1 TAW is the Belgian reference level (Tweede Algemene Waterpassing) and is located around mean water level at low tide springs. 
homogeneous zones with each having a different grain size. The corresponding standard deviation is also shown (black bars).

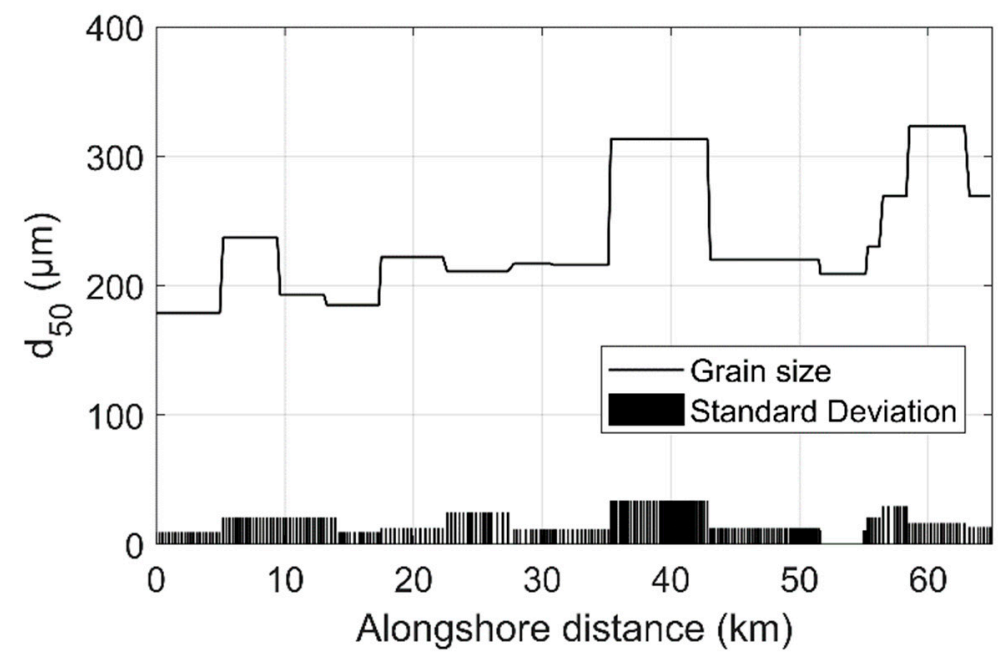

Figure 4. The grain size variation along the Belgian coast. There is an increase from France $(0 \mathrm{~km})$ to the Netherlands $(65 \mathrm{~km})$.

Approximately half of the Belgian coast consists of vegetated coastal dunes (Figures 1 and 5), which vary in height between $+5 \mathrm{~m}$ TAW and $+30 \mathrm{~m}$ TAW, with most ranging between +7 and $+15 \mathrm{~m}$ TAW [28]. According to Lebbe et al. [26], the width of the Belgian dunes narrows down from $2 \mathrm{~km}$ west of the IJzer estuary to a few hundred meters eastwards of the IJzer. Landward of the dunes, an outstretched and extensive coastal lowland is present at elevations between +1 and $+4 \mathrm{~m}$ TAW [28]. The remaining part of the Belgian coast, especially around coastal cities, is protected by harbors, groins, seawalls, and sea dykes (Figure 5). The height of the sea dykes is approximately $+9 \mathrm{~m}$ TAW.

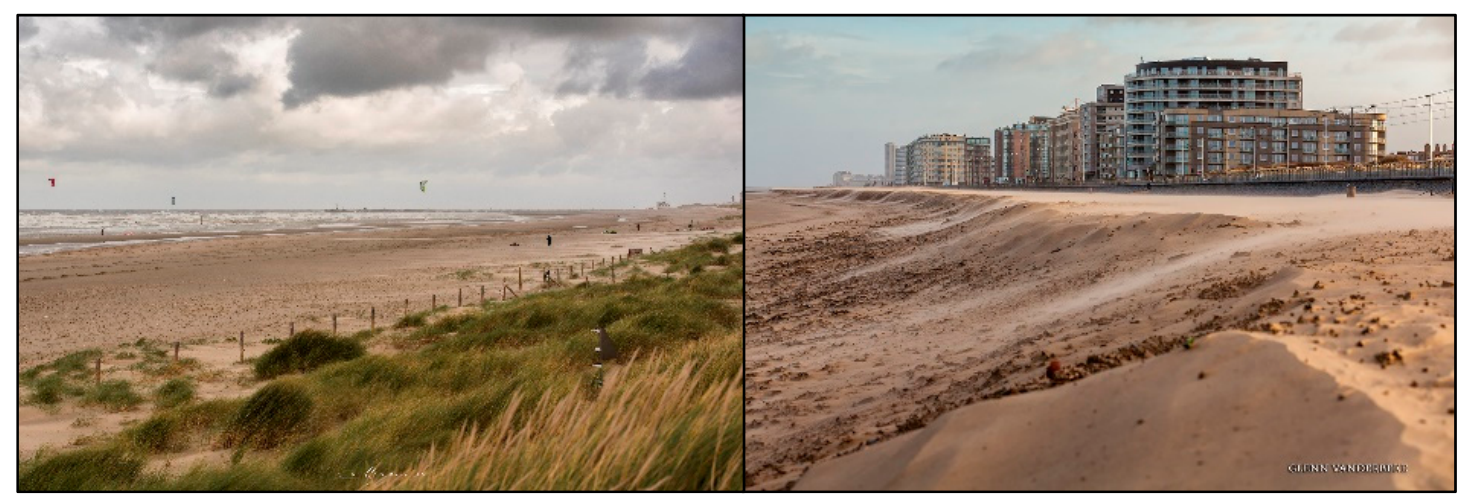

Figure 5. Typical sights at the Belgian coast. Left: natural beach-dune system at Koksijde (11 km from the French border). Right: managed beach-dyke system at Mariakerke (26 km from the French border).

\section{Methods}

\subsection{Dune Volume Changes Along the Belgian Coast}

Since 1979, the Belgian government has been monitoring the eastern part of the coastline, and since 1983 , the entire coastline by either annually or bi-annually surveying cross-shore bathymetric profiles and collecting airborne photogrammetric and, since 1999, airborne laser scanner (LiDAR) data [29,30]. The surveys took place at different times per year. Determining and managing the seawall safety level was the initial idea to monitor and survey the coastal morphology in Belgium [31]. The available data allows for specific morphological analyses. Demonstrated by numerous studies, LiDAR data is able to 
accurately represent beach topography over large stretches of coastline [32-34]. Sequentially, LiDAR surveys allow to very accurately monitor temporal shoreline changes [35]. Concerning the Belgian coast, LiDAR data covers the intertidal beach up to the sea-fronting dunes. For this study, the focus lies on the dunes. The Belgian coast is represented by a system of coastal sections adopted by the Flemish government, defined by fixed boundaries, which are also used in this study [24]. There are 277 coastal sections, each approximately $250 \mathrm{~m}$ wide, where morphology is monitored and surveyed. Section 1 is located, however, in France and sections 256 to 277 are located in the Netherlands. Hence, this study focusses on sections 2-255 (Figure 1).

In the 1980s, on the basis of elevation boundaries, the Belgian coast was also divided into five cross-shore horizontal elevation slices [29,30]. Following Figure 6, slice 1 comprises the intertidal beach with elevations between +1.39 and +4.39 m TAW, slice 2 is the dry beach with elevations between +4.39 and $+6.89 \mathrm{~m}$ TAW, slice 3 represents the dune area above $+6.89 \mathrm{~m}$ TAW, slice 4 is the shoreface with elevations between $-4.11 \mathrm{~m}$ and $+1.39 \mathrm{~m}$ TAW, and slice 5 is the sea bottom below $-4.11 \mathrm{~m}$ TAW. Initially, these elevations were defined by the Department of Mobility and Public Works (MOW) relative to the $\mathrm{Z}$ vertical datum ( $-4 \mathrm{~m}, 1.5 \mathrm{~m}, 4.5 \mathrm{~m}$, and $7 \mathrm{~m} \mathrm{Z}$ ). Later, these were converted to the TAW vertical datum by subtracting $0.11 \mathrm{~m}$. The elevations are conventional boundaries and have not been derived on the basis of tidal water level variations [24].

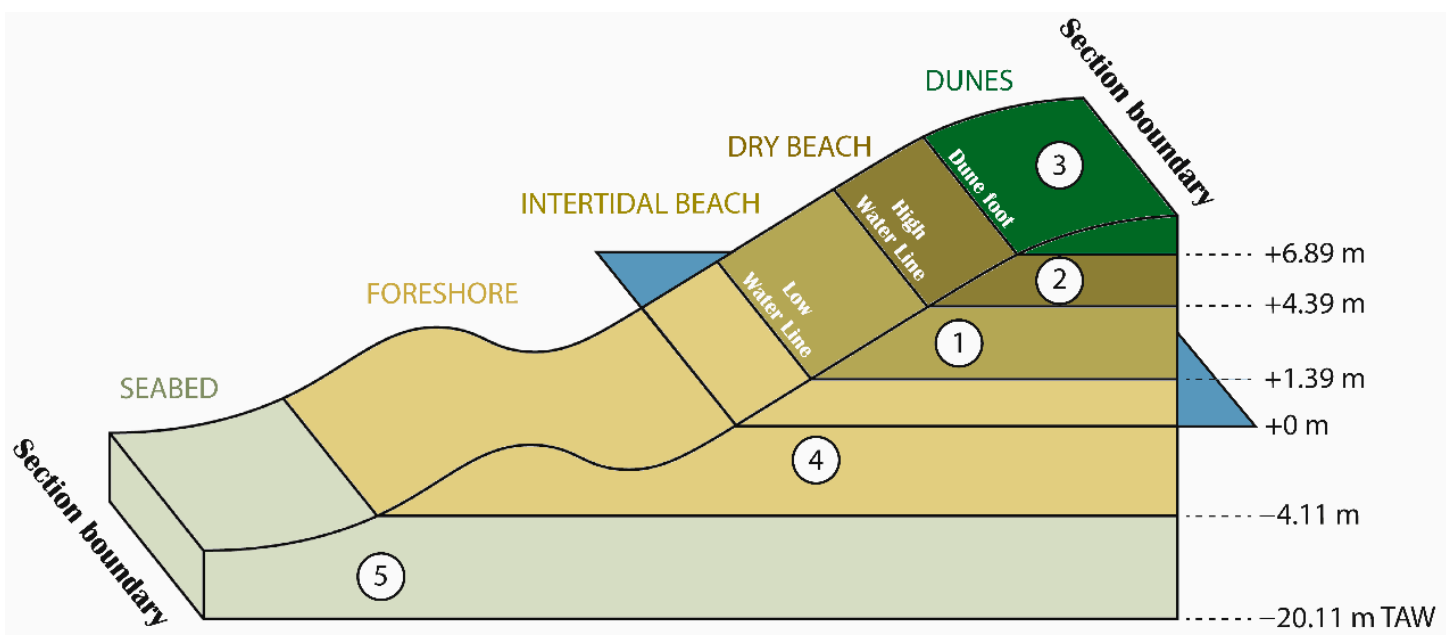

Figure 6. The definition of the dune volume (number 3), where the dune foot level starts at $+6.89 \mathrm{~m}$ TAW (Tweede Algemene Waterpassing). Figure adapted from [24].

The dune volume is defined as the volume of sand above the dune foot level and is bounded by fixed vertical planes constituting a fixed landward limit. The dune foot level along the Belgian coast was defined at $+6.89 \mathrm{~m}$ TAW. The term dune volume has been defined purely based on bounding planes. It results in a dune volume that can also be calculated in areas with a seawall or with artificially raised touristic berms, where no vegetated dunes are found. It is noticed that the landward limit is either positioned at the foot of the seawall, or on the top, or even at the landward side of the first dune ridge. However, the varying landward reference is not of relevance, given that most morphological changes occur in the area included in the section boundaries.

Figure 7 gives an overview of all the available dune volume data with respect to the first survey at the Belgian coast. Blank bars indicate no performed LiDAR flights and thus no available survey data. Some regions (especially the dune regions) experience a growth in time (yellow to red color). Other regions (in particular the regions that are diked) remain stable in time. 


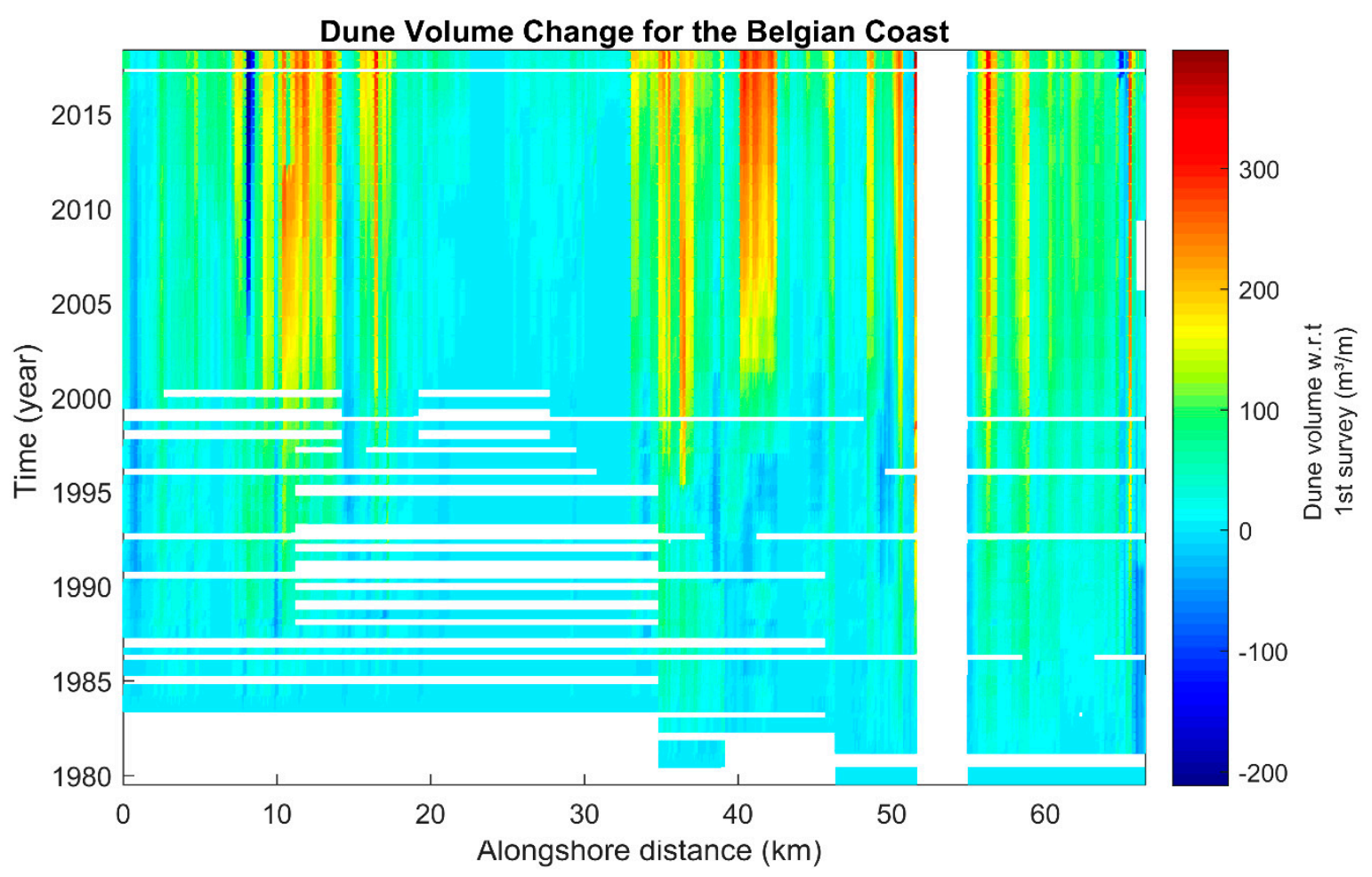

Figure 7. Overview of available data on dune volume with respect to the first survey along the Belgian coast, based on the annual surveys (positive values = deposition; negative values = erosion; $0=$ stable). The term dune volume has been defined purely based on bounding planes. Dune volume can also be calculated in areas with a seawall or with artificially raised touristic berms, where no vegetated dunes are found.

\subsection{Calculation Procedure of Potential Transport}

Dune growth could be best explained by potential aeolian sediment input from the beach into the dunes. By applying a time series of regional wind data to aeolian transport equations, potential aeolian transport can be calculated $[23,36]$. It should be mentioned that potential transport is the maximum transport that can be achieved. All winds above the threshold velocity can transport sand, disregarding all factors which negatively influence aeolian sediment transport, such as precipitation and surficial moisture [37]. Validated by short-term field campaigns [14], where wind speeds and saturated aeolian transport rates were measured, a modified Bagnold model [38] is used to calculate annual potential aeolian sand transport and is formulated by:

$$
\mathrm{q}=\left\{\begin{array}{r}
3600 \cdot \alpha_{\mathrm{B}} \cdot \sqrt{\frac{\mathrm{d}_{50}}{\mathrm{~d}_{50, \text { ref }}}} \cdot \frac{\rho_{\text {air }}}{\mathrm{g}} \cdot\left[\left(\mathrm{u}_{*}\right)^{3}-\left(\mathrm{u}_{*, \mathrm{cr}}\right)^{3}\right], \mathrm{u}_{*}>\mathrm{u}_{*, \mathrm{cr}} \\
0, \mathrm{u}_{*}<\mathrm{u}_{*, \mathrm{cr}}
\end{array}\right.
$$

where $\mathrm{q}=$ saturated mass flux $(\mathrm{kg} / \mathrm{m} / \mathrm{h}) ; \mathrm{d}_{50}=$ median particle size $(\mu \mathrm{m}) ; \mathrm{d}_{50, \text { ref }}=250 \mu \mathrm{m} ; \rho_{\text {air }}=$ density of air $\left(1.2 \mathrm{~kg} / \mathrm{m}^{3}\right) ; \mathrm{g}=$ acceleration of gravity $\left(9.81 \mathrm{~m} / \mathrm{s}^{2}\right) ; \mathrm{u} *$ = shear velocity $(\mathrm{m} / \mathrm{s}) ; \mathrm{u} *$,cr $=$ threshold shear velocity $(\mathrm{m} / \mathrm{s}) ; \alpha_{B}=$ Bagnold factor (1.5-3.5). The coefficient $\alpha_{B}$ ranges from 1.5-3.5 and is dependent on the surface sediments. A value of $\alpha_{B}=2$ represents naturally graded sands, which is used in the calculation of potential transport. Apart from the wind speed, Equation (1) assumes conditions where all parameters are considered constant in time, making the transport variability solely dependent on the variability in wind speed [4]. 
The critical shear velocity of dry sand is defined as:

$$
u_{*, \text { rr }}=0.10 \cdot \sqrt{\left[\left(\frac{\rho_{\mathrm{s}}}{\rho_{\text {air }}}-1\right) \cdot g \cdot d_{50}\right]}
$$

where $\rho_{\text {air }}=$ density of air $\left(1.2 \mathrm{~kg} / \mathrm{m}^{3}\right) ; \rho_{\mathrm{s}}=$ absolute density of sand grains $\left(2650 \mathrm{~kg} / \mathrm{m}^{3}\right) ; \mathrm{g}=9.81 \mathrm{~m} / \mathrm{s}^{2}$; $\mathrm{d}_{50}=$ median sand grain size $(\mathrm{m})$.

The shear velocity, $u_{*}$, is the main driving factor in most transport formulae [39,40]. Determining the shear velocity, $u_{*}$, requires either measurement of the velocity profile or knowledge of the aerodynamic roughness length [41]. A time series of hourly mean wind speed and wind direction were obtained from a meteorological station maintained by Ostend Airport. The station is about $1 \mathrm{~km}$ inland from the coastline and measured at a height of $4 \mathrm{~m}$ (Figure 1). The wind data is available since the year 2000. It is likely that the roughness length varies significantly spatial-temporally [9]. This makes it inappropriate to use any of the frequently used transport formulae [41].

Hsu [21] suggested a straightforward equation for the prediction of aeolian sediment transport from hourly routine wind observations at meteorological stations. The equation is based on the relationship between the bed shear velocity, $\mathrm{u}_{*}$, and wind speed at a certain height above the surface, taken from field data from numerous study areas. This relationship for the dry beach area is given by $\mathrm{u}_{*}=0.040 . \mathrm{U}_{2 \mathrm{~m}-10 \mathrm{~m}}$, where $\mathrm{U}_{2 \mathrm{~m}}$ and $\mathrm{U}_{10 \mathrm{~m}}$ is the wind speed at $2 \mathrm{~m}$ and $10 \mathrm{~m}$ above the surface, respectively. This relationship is also the average value found by Strypsteen et al. [9]. In the potential aeolian sand transport calculations, the wind shear velocity, $u^{*}$, is constant throughout the hour, in spite of the fact that this is practically not the case. Normally distributed fluctuations around the mean wind speed would cause, in theory, a larger amount of sediment to be transported by wind than would be given here [10]. According to Sarre [10], these inaccuracies and underestimations of potential aeolian transport are not important. Other transport limiting factors in coastal areas are of more importance, such as surface moisture, vegetation and beach dimensions [4].

Potential sediment transport will also be influenced by the fetch effect [42,43]. Delgado-Fernandez [43] described the effect of fetch length as an increase in sediment transport rate in the downwind direction until an equilibrium is reached. Longer fetch lengths often lead to higher transport rates under certain wind conditions. The limit where an equilibrium is reached is defined as the critical fetch. Critical fetch distance is not considered in this paper, since it is in the order of 10-50 $\mathrm{m}$ for wind speeds up to $15 \mathrm{~m} / \mathrm{s}$ [44] and it is smaller than the average upper beach width at the Belgian coast.

Applying a measured wind time series produces the total transport by summation of all calculated transport rates, $\mathrm{q}_{\mathrm{i}}$ (Equation (2)). It is of great importance that potential aeolian sediment transport is being modified according to the angle of wind approach along the shoreline in order to compare predicted with observed dune volume changes [1]. The predicted net sediment input by wind in the dunes (in $\mathrm{m}^{3} / \mathrm{m}$ ) becomes:

$$
\mathrm{Q}_{\text {cross-shore }}=\frac{1}{\rho_{\mathrm{b}}} \sum_{\mathrm{i}=1}^{\mathrm{n}} \mathrm{q}_{\mathrm{i}} \sin [\alpha-\mathrm{O}]=\frac{1}{\rho_{\mathrm{b}}} \sum_{\mathrm{i}=1}^{\mathrm{n}} \mathrm{q}_{\mathrm{i}} \sin \left[\mathrm{dd}_{\mathrm{j}}\right]
$$

Parallel or longshore winds should be modified by the cosine of the transport direction:

$$
\mathrm{Q}_{\text {longshore }}=\frac{1}{\rho_{\mathrm{b}}} \sum_{\mathrm{i}=1}^{\mathrm{n}} \mathrm{q}_{\mathrm{i}} \cos \left[\mathrm{dd}_{\mathrm{j}}\right]
$$

where the angle, $\mathrm{dd}_{\mathrm{j}}$, is the difference between the wind direction $\alpha$ and the coastal orientation, $\mathrm{O}$ (Figure 8); $n$ equals the total amount of hours in the measured time series, while assuming a bulk density of sand of $1600 \mathrm{~kg} / \mathrm{m}^{3}\left(\rho_{\mathrm{b}}\right)$ (e.g., $\left.[38,45]\right)$. Hence, predicted sediment transport can be compared to 
observed dune volume changes in consecutive periods where (oblique) onshore winds were exceeding the threshold velocity.

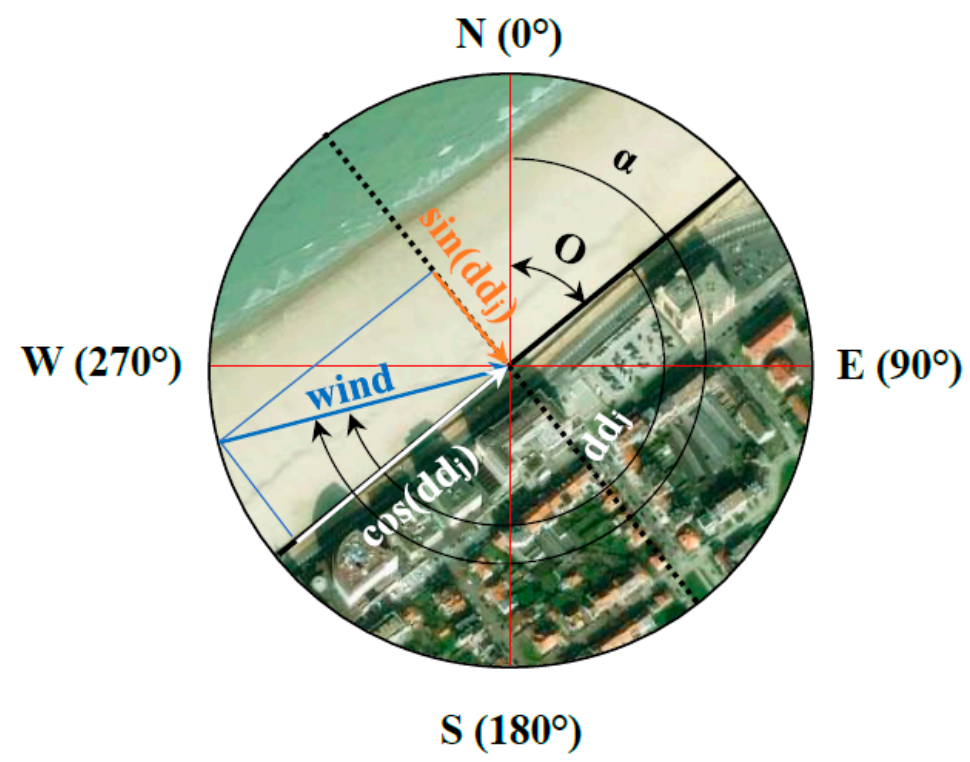

Figure 8. Orientation $(\mathrm{O})$ of the Belgian coastline and calculation procedure of potential transport. The orange arrow shows the onshore direction of sediment transport towards the dunes and is used to explain dune behavior. The angle $\alpha$ is the wind direction (with respect to the north) and the angle $\mathrm{dd}_{j}$ is the difference between the wind direction and coastal orientation $\mathrm{O}$.

\section{Results and Discussion}

\subsection{Spatial-Temporal Variability in Dune Volume Changes: Linear Trends}

As an illustrative example of an analysis at a natural dune system, Figure 9 shows the dune volume at section 50 of the Belgian coast. It is found that dune volume increases to a good approximation at a constant rate in time $\left(8.14 \mathrm{~m}^{3} / \mathrm{m} /\right.$ year with a correlation of 0.99$)$. To assess if this trend is valid for all coastal dunes, the decadal trend in the calculation of dune volume changes is based on linear regression analysis. Fitting linear trendlines for all the coastal sections can show to what extent this linearity in time is valid for the entire Belgian coastline. Linear trends are calculated for the entire period between 1979-2018 and/or for the most recent trend. The correlation coefficient was calculated for all dune sections experiencing dune growth or dune erosion. Figure 10 shows that higher correlation coefficients occur more for dune growth than for dune erosion. It is found that $80 \%$ of all coastal dunes with dune growth (total of 93\%) have correlation coefficients higher than or equal to 0.9 , which yields an overall average dune growth of $6.20 \mathrm{~m}^{3} / \mathrm{m} /$ year. This percentage decreases for smaller correlation coefficients. Similar observations are found by de Vries et al. [4]. For the negative rates of dune volume change $(7 \%$ of all coastal dunes), the occurrence of a lower correlation coefficient increases. These calculations show that a substantial part of Belgian coastal dunes is excellently represented using a linear dune growth model in time. Figure 11 indicates that the locations of the coastal dunes, with correlation coefficients larger than 0.9, are distributed over the total stretch of the Belgian coast. Figure 11 also shows the annual dune development per dune section for the entire Belgian coastline. It is observed that in most areas, dunes are growing. The annual dune growth ranges between $0-12.3 \mathrm{~m}^{3} / \mathrm{m} /$ year, based on observations between 1979-2018. Dune growth rates at the Holland coast have been calculated in the order of $0-40 \mathrm{~m}^{3} / \mathrm{m} /$ year, which is in the same order of magnitude [4]. 
In some beach sections along the Belgian coast, management activities are carried out which have a direct influence on dune development. In the following paragraphs, some typical management strategies and their effect on dune behavior are described in more detail.

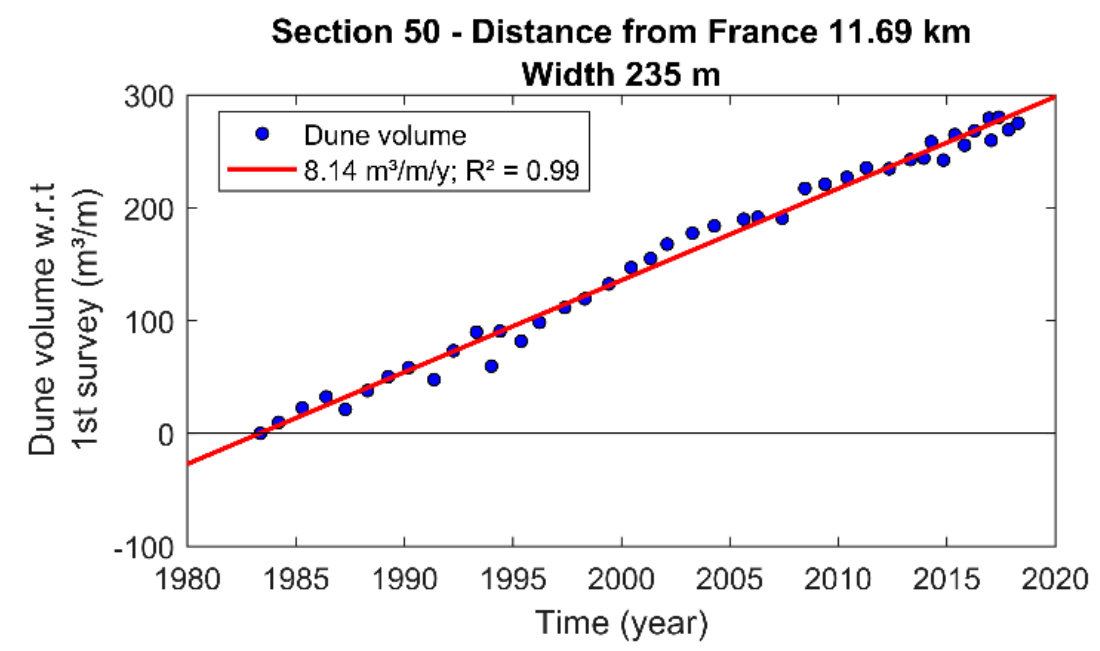

Figure 9. Example of dune volume in time combined with a linear fit (correlation of determination $\mathrm{R}^{2}=0.99$ ) for coastal section 50 (natural dunes).

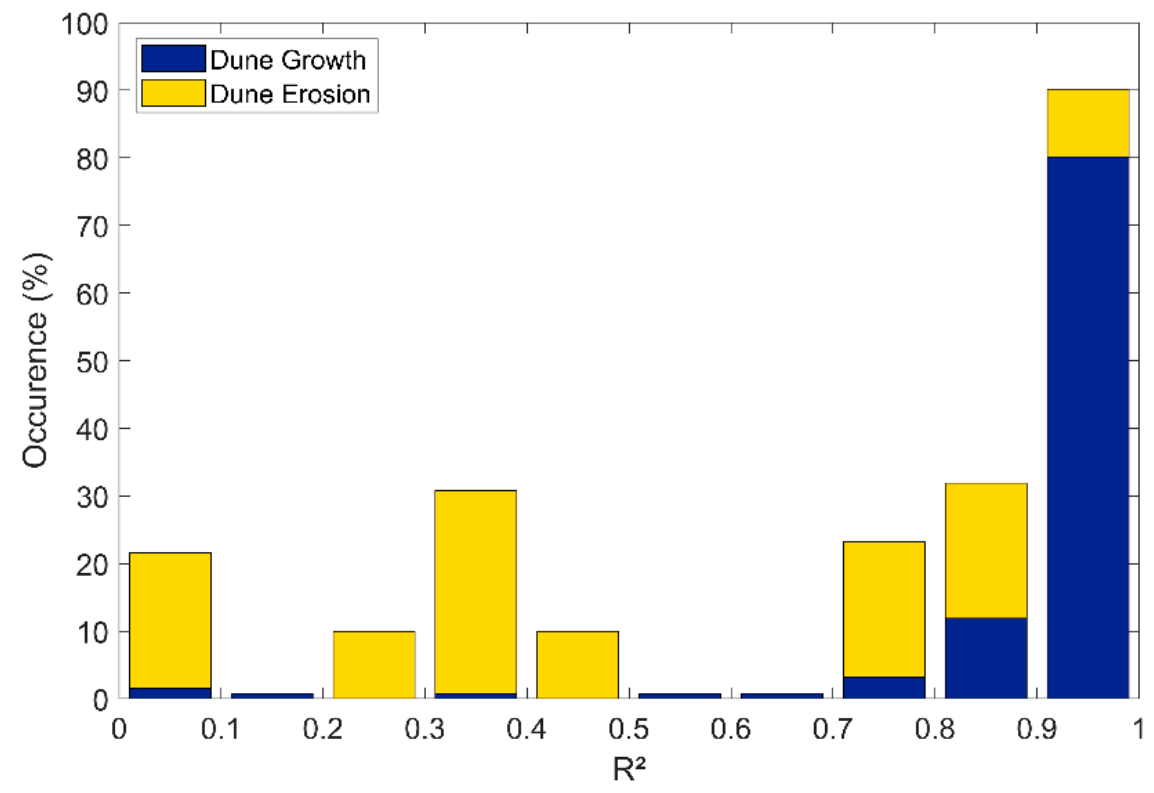

Figure 10. Density of occurrence of linear dune behavior. Of the dune sections, $80 \%$ show correlation coefficients larger than or equal to 0.9 . 


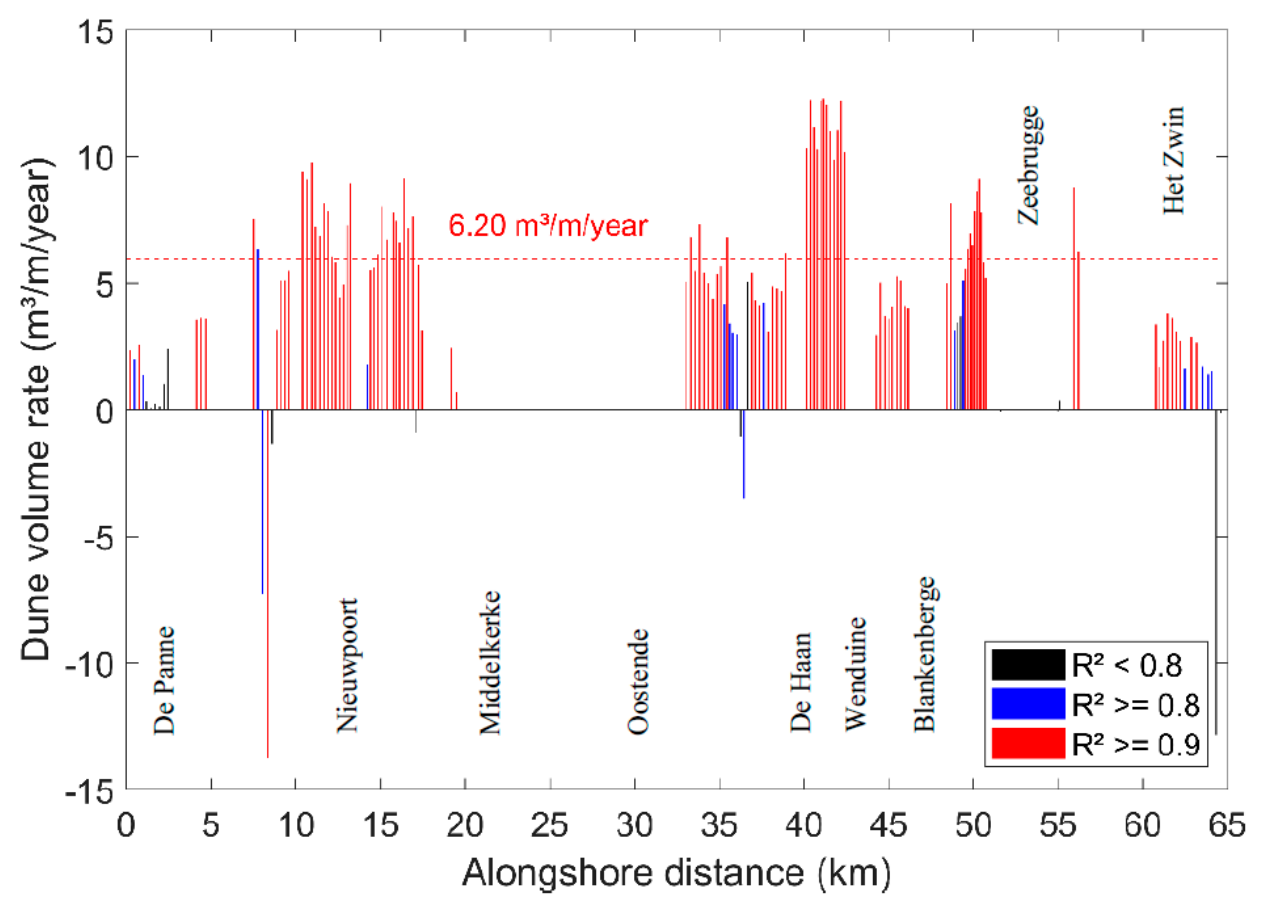

Figure 11. Dune behavior along the Belgian coast for all sections with vegetated dunes (approximately half of the coast). Red bars indicate the places where the correlation coefficient of the linear trend analysis is higher than or equal to 0.9 . The red dashed line represents the average annual dune growth for correlations higher than or equal to 0.9 .

\subsection{Typical Management Strategies and Their Effect on Dune Behavior}

\subsubsection{Influence of Dune Foot Reinforcement}

Figure 12 shows dune volume changes between 1983 and 2018 for section 8 . In the past, section 8 , close to the French border, experienced intense dune erosion during storm events. For coastal safety, a dune foot reinforcement was constructed (concrete dyke) in the period 1976-1979. In 1990, this concrete dyke was extended on the east side after a severe storm surge. Massive erosion in the coastal zone was caused by heavy storms at the beginning of 1990 and storms in the period 1993-1994. In a part of section 8, a concrete wall was erected in 1994 above the dune foot reinforcement (Figure 13). Sand was also applied above the dune foot from the low-water line. Sand was again supplied after the storms of 1-2 January 1995, 19 February 1996, 29 August 1996 and 29 October 1996. Due to the influence of dune foot reinforcement, the dune volume of section 8 does not experience a linear trend in time. The natural behavior of the dune has been completely blocked. As such, dune reinforcements are not suitable for climate-resilient flood protection. 


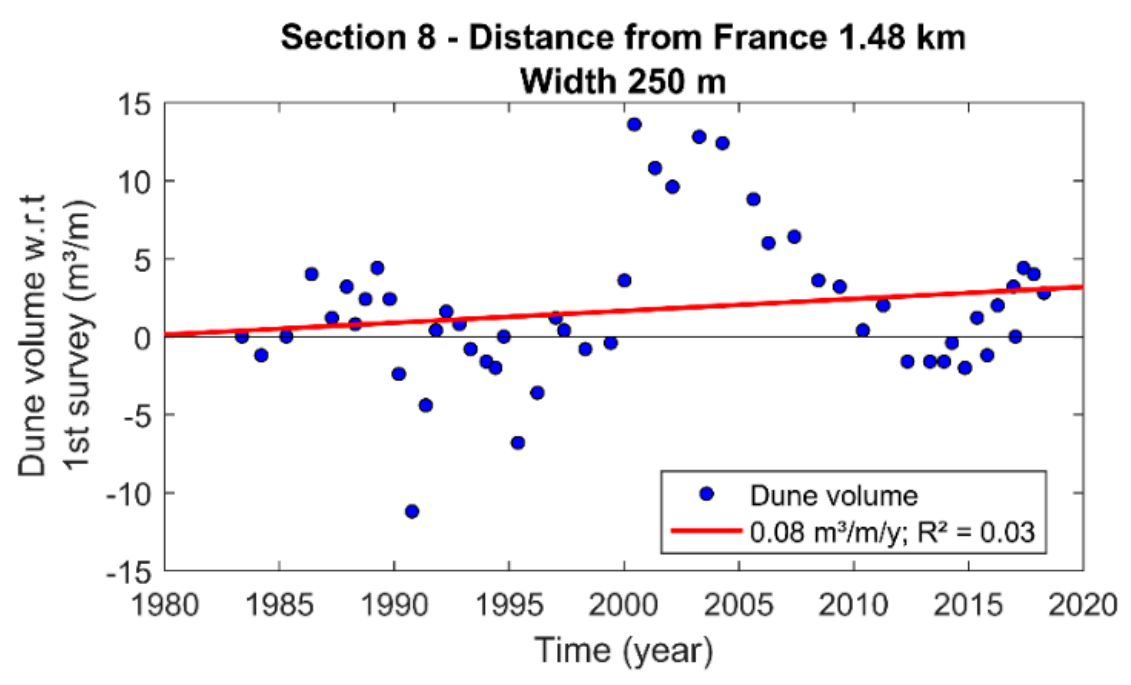

Figure 12. Decadal dune evolution of the coastal dunes at section 8.

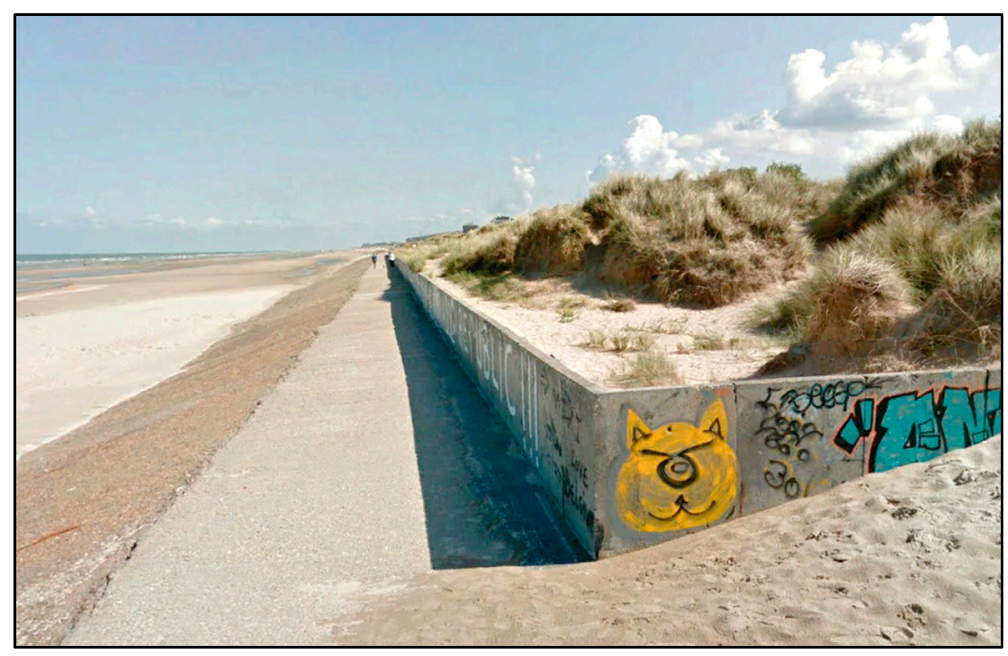

Figure 13. Concrete revetment and wall, built to reinforce the dune foot in section 8 .

\subsubsection{Effect of Dune Blowouts}

Since the airborne surveys started in 1983, the dunes of section 36 experienced a gradual linear growth in time due to aeolian sand input from the beach (Figure 14). In the beginning of the 1990s, dune erosion started to occur due to the formation of a dune blowout (Figure 15). The formation of dune blowouts tends to start at patches of bare sand, where vegetation does not grow. Wind speeds above the threshold erodes into those patches, blowing the sand out of the system. Note that the sand is feeding the dunes further inland. Because they are not covered by the LiDAR measurement, this effect is not captured. These blowouts often occur on stabilized vegetated dunes. Dune erosion was highest between 2000-2005. Since 2005, the intensity of dune erosion has decreased to $7.26 \mathrm{~m}^{3} / \mathrm{m} /$ year. 


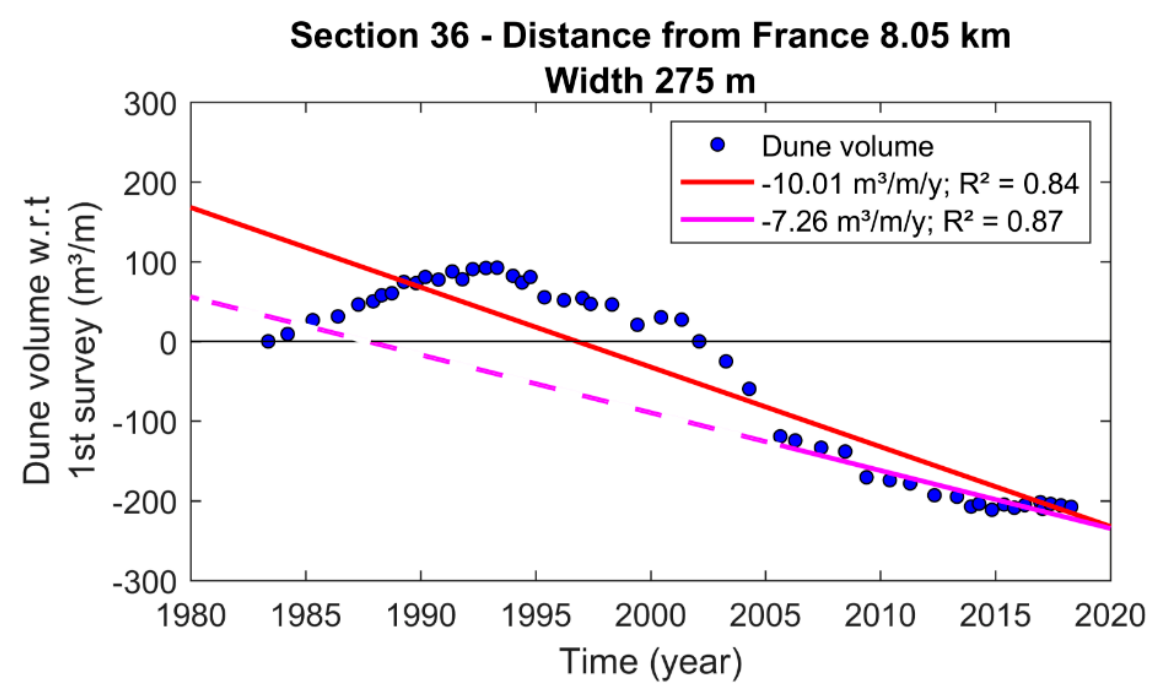

Figure 14. Decadal dune evolution of the coastal dunes at section 36 . The solid magenta line indicates the recent dune trend.

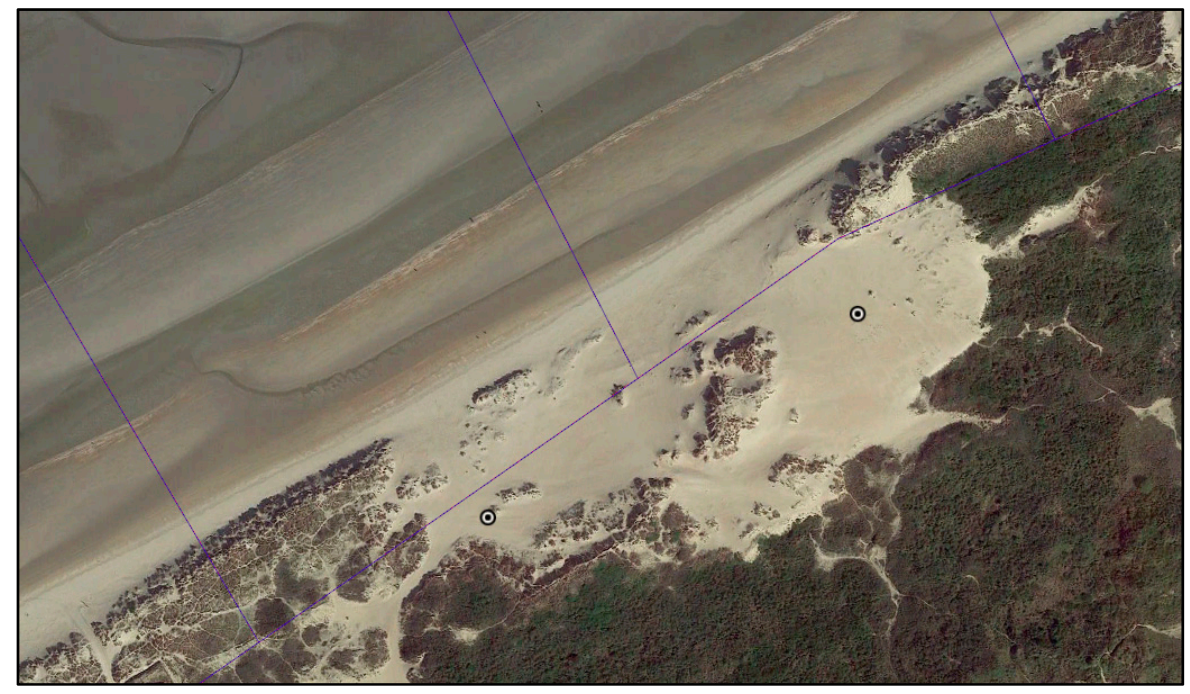

Figure 15. Dune blowouts at sections 36 to 38 .

\subsubsection{Influence of Dune Foot Protection Measures}

Figure 16 shows dune volume changes between 1983 and 2018 for section 72 . In section 72 and a part of section 73, a dune foot protection measure was constructed in 1944 in the form of a concrete wall (Figure 17), because this area experienced severe dune erosion. As an indication, the location of the dune foot of the adjacent section (section 71) is approximately $25 \mathrm{~m}$ further inland of the wall. Section 72 experienced fairly linear dune growth until 1993. Major dune erosion happened due to the heavy storms in the 1990s. Afterwards, the dunes experienced slow dune erosion or were basically stable as the dune foot could not grow further seawards. Primary embryo dune growth is difficult to develop at the dune foot and most volume variations are generally found in the dune foot region. 


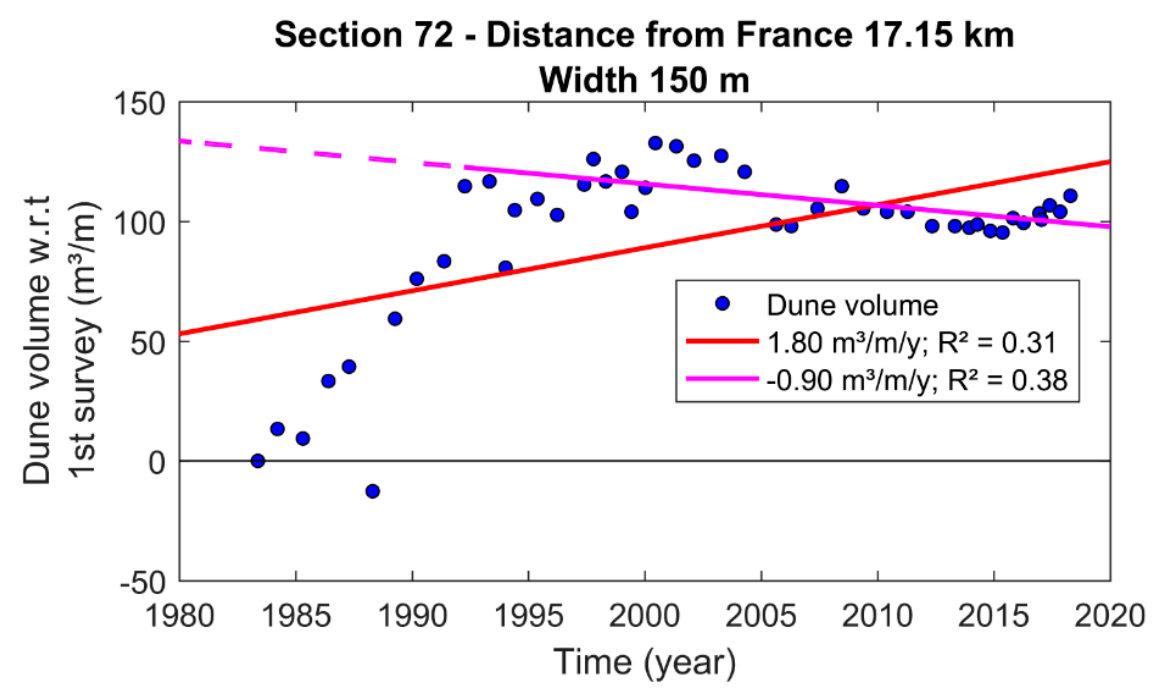

Figure 16. Decadal dune evolution of the coastal dunes at section 72 . The solid magenta line indicates the recent dune trend.
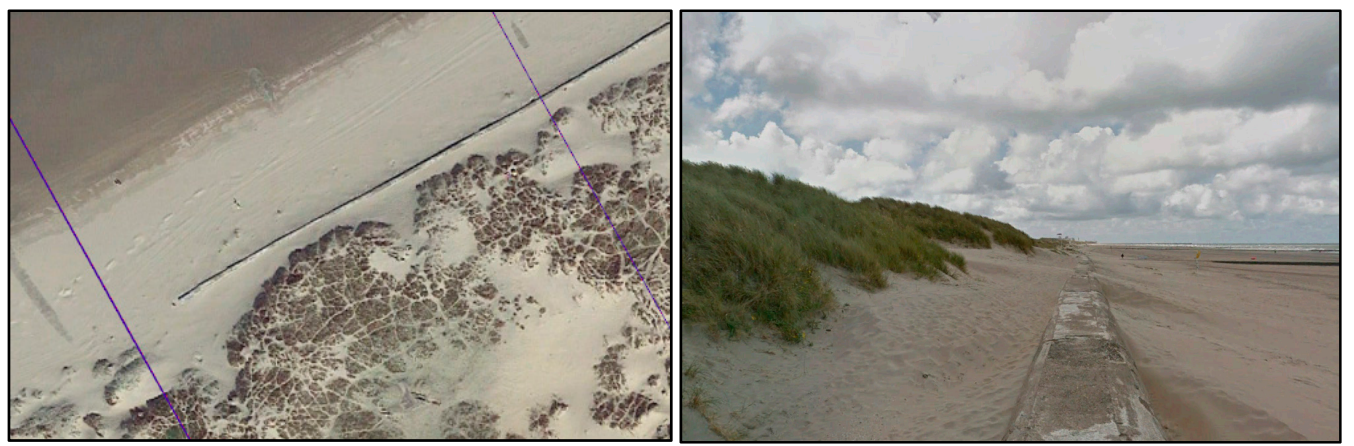

Figure 17. Concrete wall as a dune foot protection measure in section 72 .

\subsubsection{Combined Influence of Nourishments and Brushwood Fences}

Section 160 (Figure 18), located $41 \mathrm{~km}$ from the French border, was fairly stable since measurements started. However, the heavy spring storms of 1990 had particularly affected the coastal dunes in this part of the Belgian coast. Due to those storms, large-scale beach nourishments were needed. These works were carried out during the period of 1992-2000 and attributed to the creation of wide beaches and by the subsequent plantation of brushwood fences (Figure 19). The widening of the beaches enhanced aeolian sand being blown to the dunes, causing a linear growth of $12.18 \mathrm{~m}^{3} / \mathrm{m} / \mathrm{year}$, which is well above the average dune growth rate. The sand trapping efficiency of brushwood fences varies from site to site and is particularly high if the availability of sand is large [46]. 


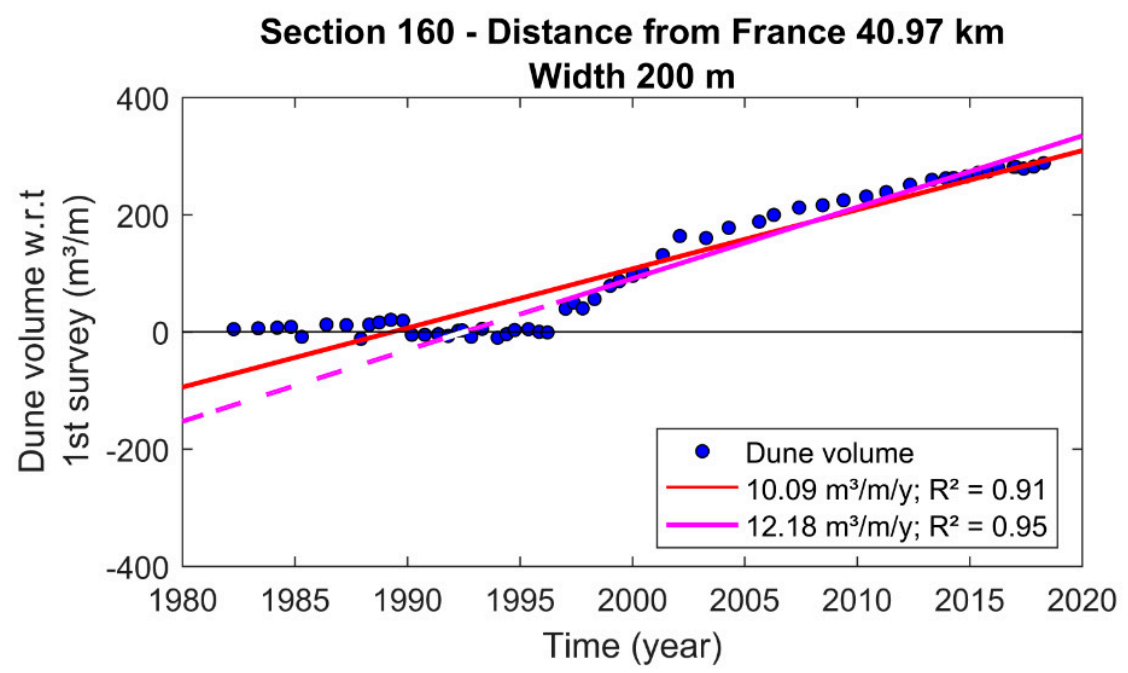

Figure 18. Decadal dune evolution of the coastal dunes at section 160 . The solid magenta line indicates the recent dune trend.

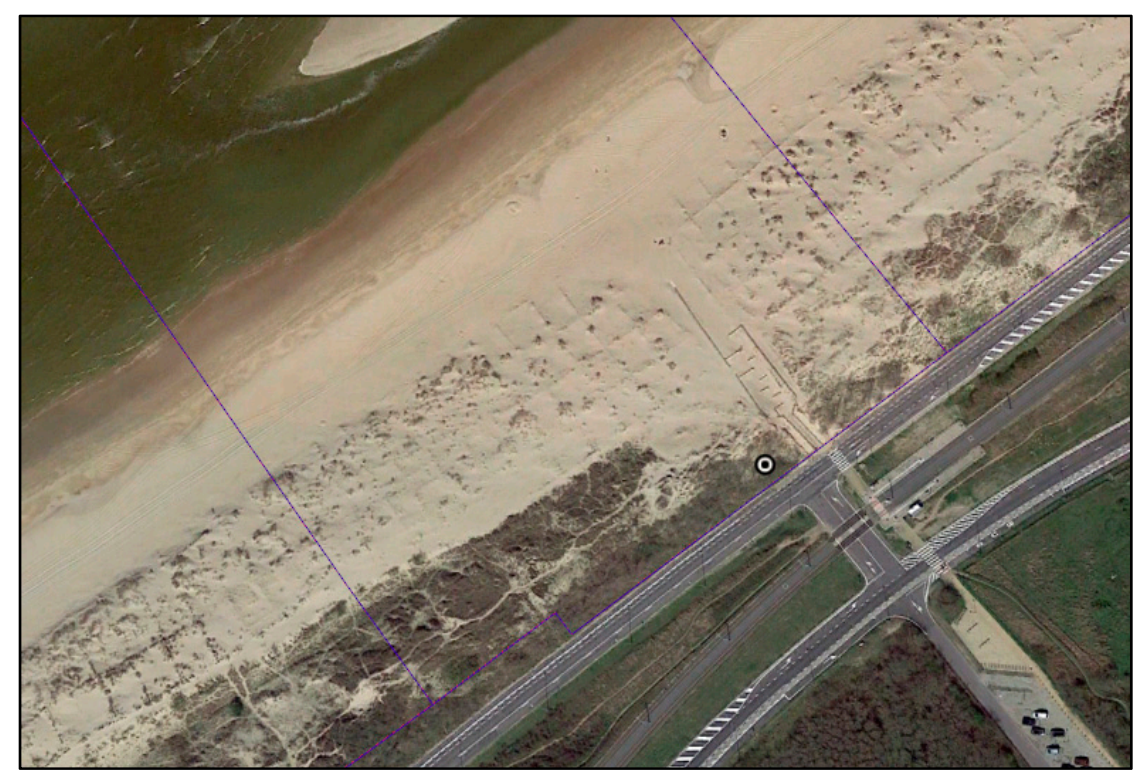

Figure 19. The dunes at section 160, showing the plantation of brushwood fences.

\subsubsection{Influence of Excavation Works}

At the Dutch border, section 254 is the last section of the Belgian coast. In section 254, the tidal channel 'the Zwingeul' is present (Figure 20). Because of its free movement, this section has large annual fluctuations in sand beach volume. The dunes grow fairly linear in time until the year 2016. In the year 2016, large dune erosion occurred in this section because of large excavation works. Since then, the dunes are continuously eroding at a rate of $-12.84 \mathrm{~m}^{3} / \mathrm{m} /$ year (Figure 21). 


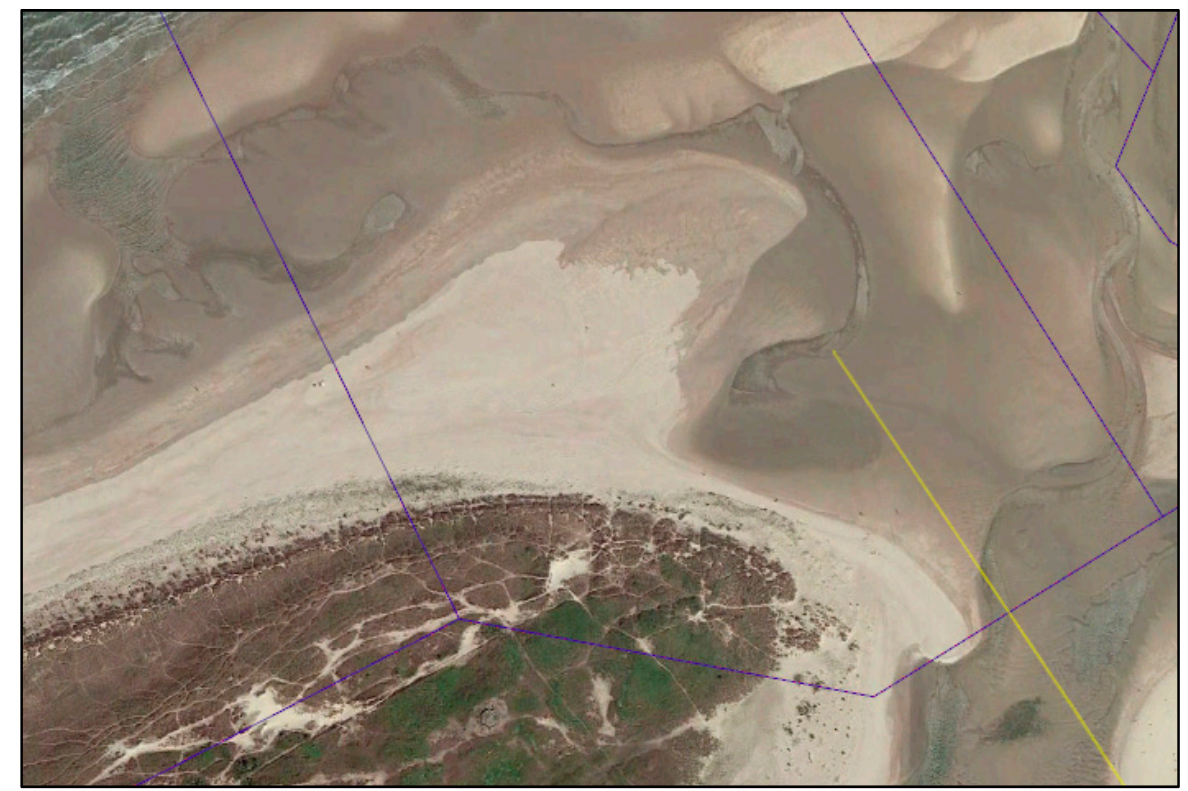

Figure 20. Tidal channel 'the Zwingeul' (sections 254 and 255).

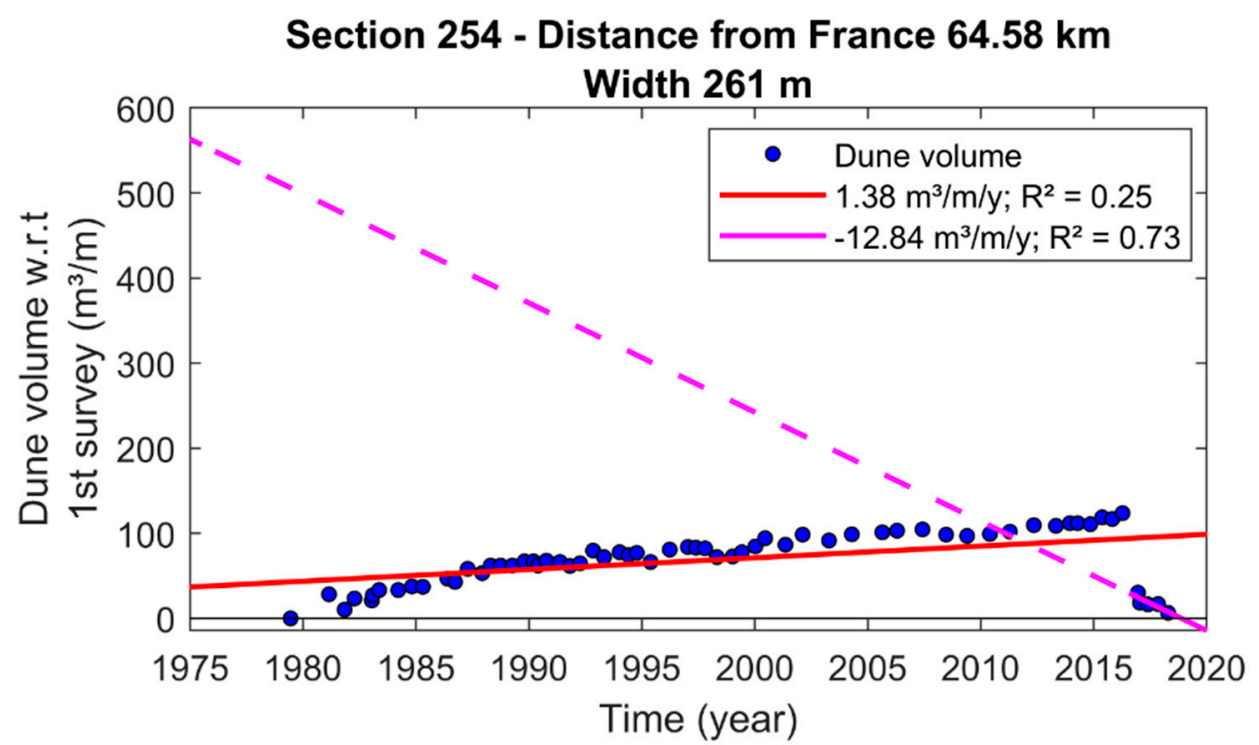

Figure 21. Decadal dune evolution of the coastal dunes at section 254. The solid magenta line indicates the recent dune trend.

\subsection{Potential Aeolian Sediment Transport}

It is well known that dune growth is primarily governed by aeolian sediment processes. Therefore, expectations are that dune volume variability does correlate with variability in wind conditions. Potential aeolian sediment transport is calculated per coastal dune section between the dates where a LiDAR flight is conducted using the representative median grain size and coastal orientation. Hourly wind data is available since the year 2000 at Ostend Airport (middle of the coastline and approximately $1 \mathrm{~km}$ inland) and is used to calculate the time series of potential transport. The wind sensor is located $4 \mathrm{~m}$ above the surface. Figure 22 shows the measured wind data at the weather station of Ostend Airport for the period 2000-2017 in the form of a wind rose. The red line represents the mean direction of the Belgian coastline. Measured over that period, a large west to southwest component of the wind is found. West to southwestern winds are oblique onshore to longshore with respect to the Belgian coastline. 


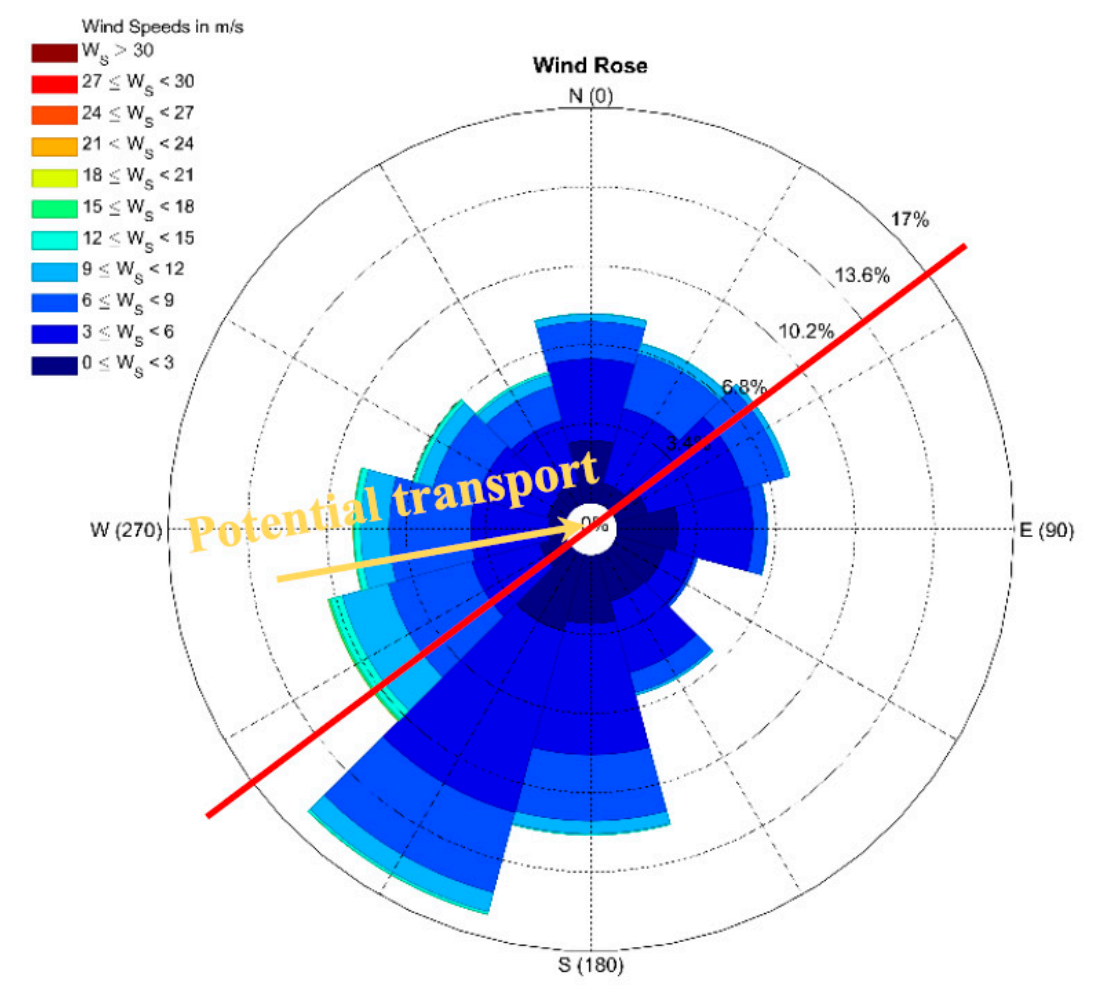

Figure 22. Measured wind speed $\left(\mathrm{W}_{\mathrm{s}}\right)$ and wind direction at Ostend Airport weather station for the period 2000-2017. The red line represents the Belgian coastline direction. The potential transport drift is also given.

Figure 23 shows the annual potential transport and transport direction for the period 2000-2017 derived from measurements at Ostend Airport weather station based on a grain size of $310 \mu \mathrm{m}$ and coastal orientation of $57^{\circ}$ (section 103). Figure 23 indicates considerable temporal variability, caused by annual variations in wind climate. Annual variations are approximately between 0.5 times and 1.6 times the mean transport rate, meaning that potential transport, occasionally, is three times larger for some years than other years. The average direction of potential transport over the period of 17 years is $260^{\circ}$ with a standard deviation of $14^{\circ}$, implying that the direction is constant. Potential transport has an oblique onshore character with respect to the coastline (Figure 22). The larger parallel component (longshore) of the potential transport drift is directed towards the northeast (the Netherlands), while the normal component (onshore) is directed towards the southeast.

Interpreting the results on a decadal timescale, all potential transport rates are cumulatively summed. Potential dune volume changes because of aeolian sediment transport appears to vary linearly in time with a constant rate, which in return explains the decadal linear dune growth (Figure 24). Considering all coastal dune sections within the period of 2000-2017, Figure 25 indicates that onshore potential transport maximum ranges to $9 \mathrm{~m}^{3} / \mathrm{m} /$ year (average $=5.2 \mathrm{~m}^{3} / \mathrm{m} /$ year), while longshore potential transport could reach up to a maximum of $20 \mathrm{~m}^{3} / \mathrm{m} /$ year (average $=18.7 \mathrm{~m}^{3} / \mathrm{m} /$ year), assuming dry beach sand. In return, this gives a mean total potential transport of approximately $20 \mathrm{~m}^{3} / \mathrm{m} /$ year. Longshore transport is relatively constant along the coastline ( $4.9 \%$ deviation of the mean). Onshore transport has some longshore variations due to a varying coastline orientation, especially behind the protruding point of Wenduine $(43 \mathrm{~km})$, where transport is lower due to a more north-northeast coastal orientation. It also implies that longshore transport is almost three to four times higher than onshore transport. This would explain why brushwood fences are so efficient for enhancing dune growth locally. 

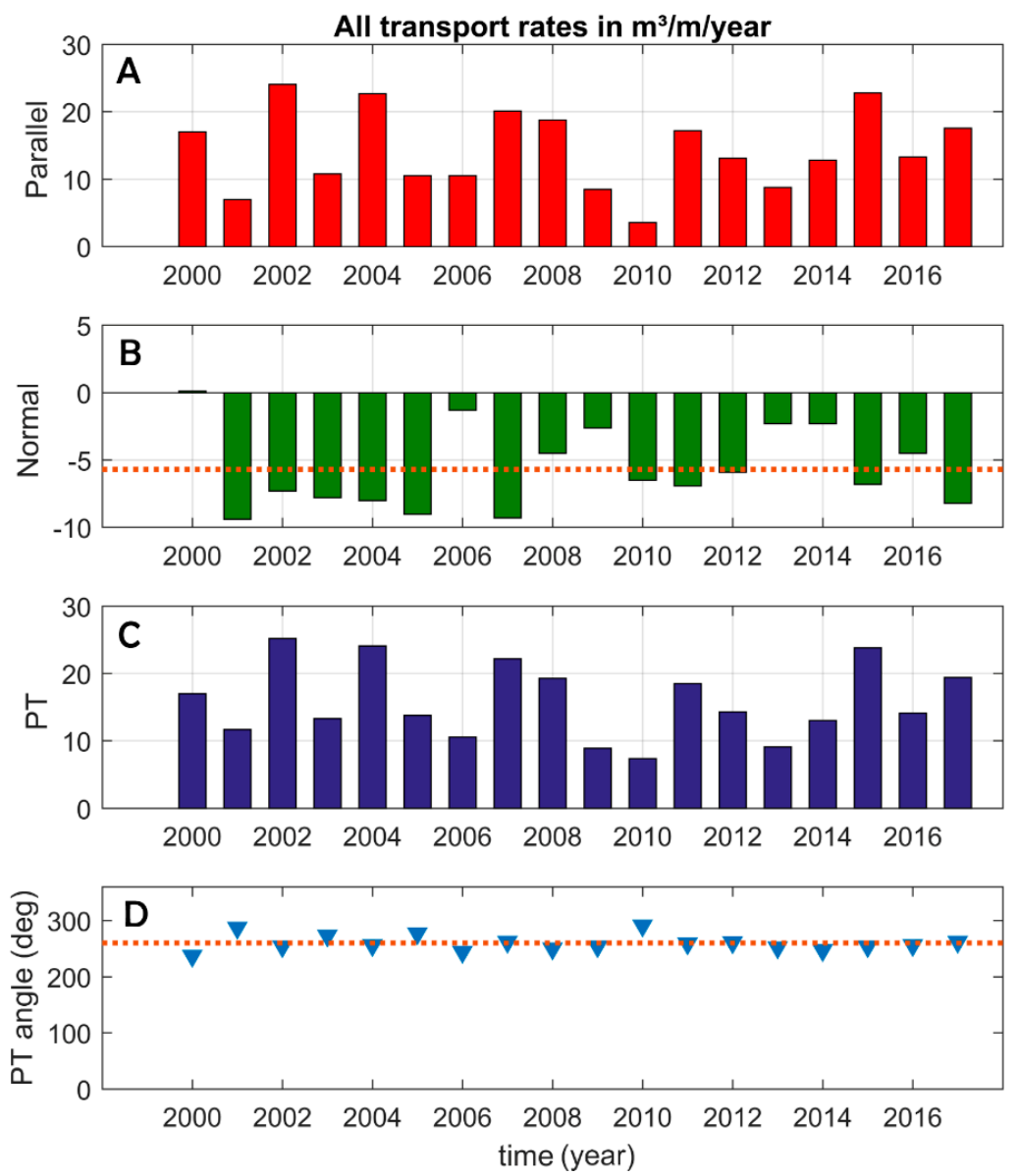

Figure 23. (A) Annual potential longshore transport for the period 2000-2017. (B) Annual potential cross-shore (or normal) transport for the period 2000-2017. Positive is offshore transport, negative is onshore transport. (C) Annual potential transport (PT) for the period 2000-2017. All transport rates are given in $\mathrm{m}^{3} / \mathrm{m} /$ year. (D) The angle of potential transport is fairly constant with an average value of 260 degrees to the north.

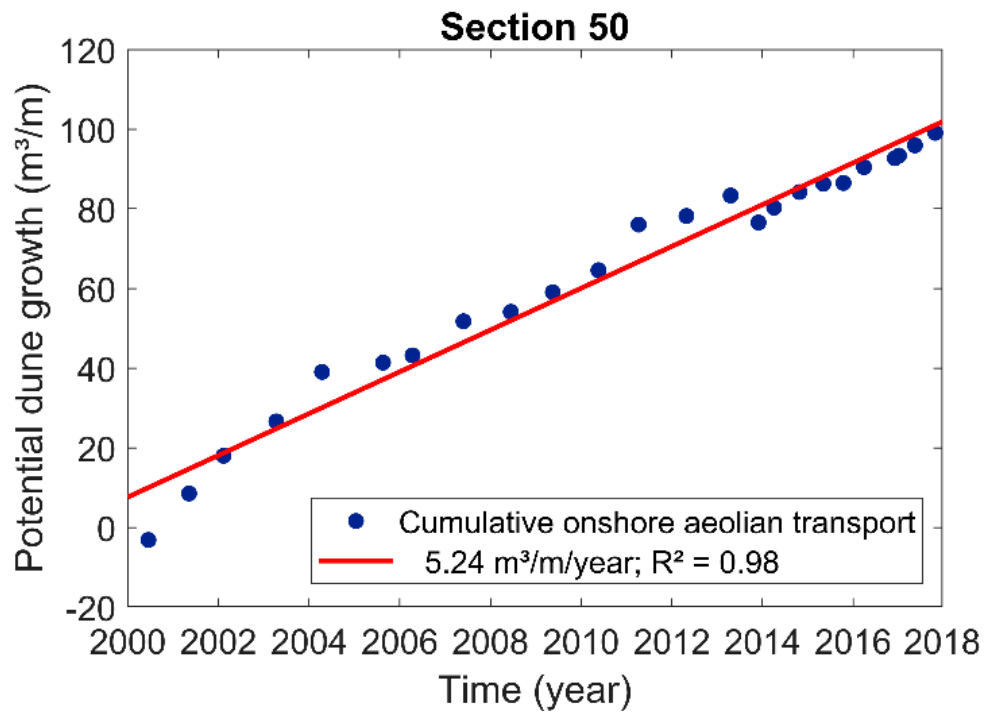

Figure 24. Decadal evolution of potential dune growth at section 50 of the Belgian coast. 


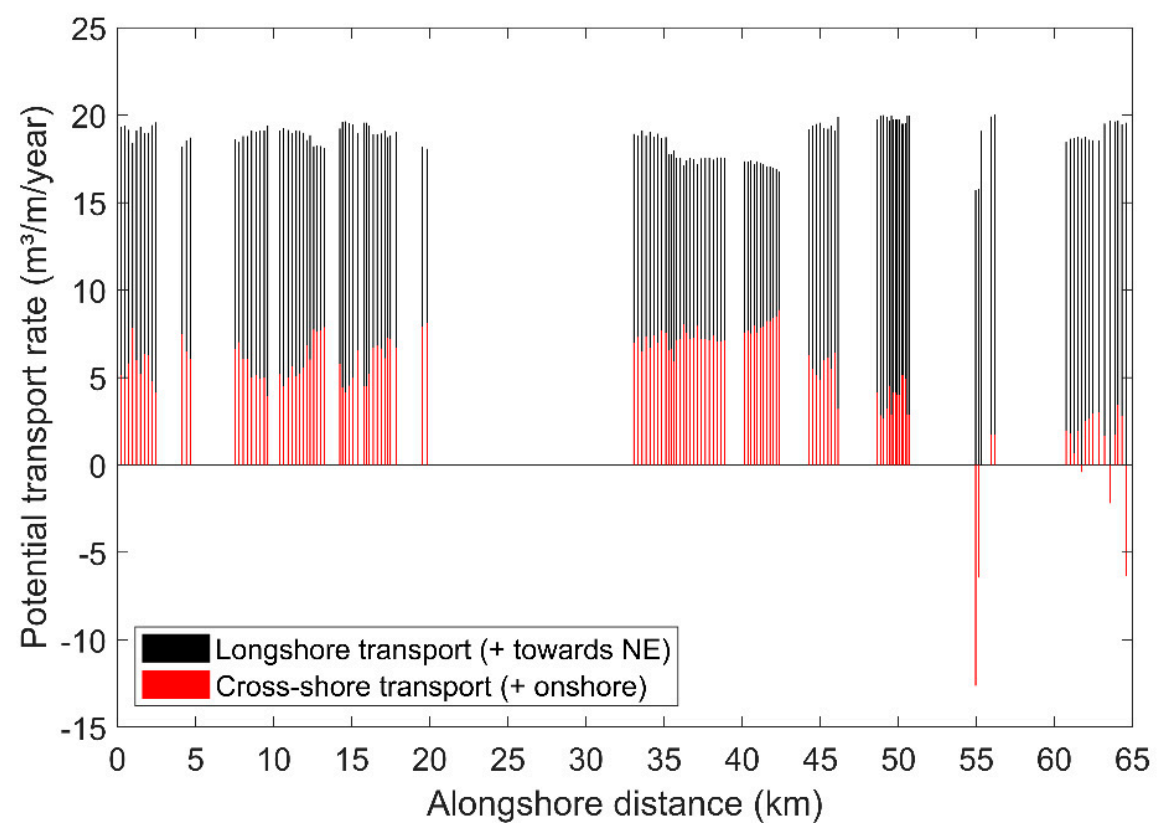

Figure 25. Annual potential longshore and onshore aeolian sediment transport, based on the period between 2000-2017.

\subsection{Correlation between Potential Transport and Dune Volume Changes}

\subsubsection{Correlation on Annual Timescales}

More wind induces more aeolian sediment transport and intuitively, therefore, more dune growth is expected [4]. To find a correlation between variation in potential transport and dune volume change on an annual timescale, the Pearson correlation coefficient is calculated. In this procedure, three methods are applied to calculate the correlation coefficient:

- Method 1: The first method compares dune erosion and dune growth with corresponding potential transport. Net potential transport is calculated based on the full wind rose (onshore and offshore winds).

- Method 2: The second method compares dune erosion and dune growth with corresponding potential transport based solely on onshore winds. It is assumed here that offshore winds do not extract sediment from the dune seawards. As mentioned before, dunes are, besides aeolian processes, also influenced by marine erosive processes.

- Method 3: The third and last method compares only the periods with dune growth with the corresponding potential transport based solely on onshore winds. Offshore winds are not used in the calculation procedure.

A positive correlation implies that an increase in potential transport causes an increase in dune volume. A negative correlation implies the opposite. However, the three methods gave similar results. No significant correlation (positive or negative) is found between potential transport and dune volume change on an annual timescale, considering all sections with coastal dunes. The poor correlation could be attributed to:

- According to Equation (1), potential aeolian sediment transport is proportional to the cube of shear velocity, meaning that high winds above the threshold contribute exponentially to the annual sum of potential transport (Equation (4)). Although these winds are able to transport large amounts of sediment, they tend to create high water levels and long wave run-ups as well. 
- Between consecutive LiDAR flights, dune erosion and dune growth can occur. Even during strong aeolian transport events, a single dune-erosion event can undo any dune growth that happened before that storm.

- The period between two consecutive LiDAR flights is also too long, resulting in a coarse spatial-temporal data set.

- Dune volume changes can be influenced by the sediment supply and sediment availability from the marine zone $[4,16]$. Transport limiting factors, such as sediment size and distribution, beach geometry and moisture can be of more importance than the driving wind speed.

\subsubsection{Correlation on Decadal Timescales}

Decadal timescales are of interest because it is the most appropriate timescale for engineering purposes and coastline development. On decadal timescales, potential dune volume appears to grow linearly with time, with a similar magnitude to the observed dune volume (see Section 4.3). It is of particular interest if both are correlated at this spatial-temporal scale. For all coastal dune sections, the decadal trend of potential dune volume changes is based on linear analysis. Linearity is calculated for the entire period between 2000-2017. It is found that in $93 \%$ of all coastal dune sections, the potential dune volume trend has a correlation higher than 0.90 .

Figure 26 shows the comparison between observed and predicted dune development on decadal timescales. The yellow dots show the places were regular management activities are carried out. About $75 \%$ of all predicted data are within a factor of two of the measured values. Interpreting the results show that the modified Bagnold model based on Equation (1) [38] yields a good performance when observed values are compared to predicted dune development rates.

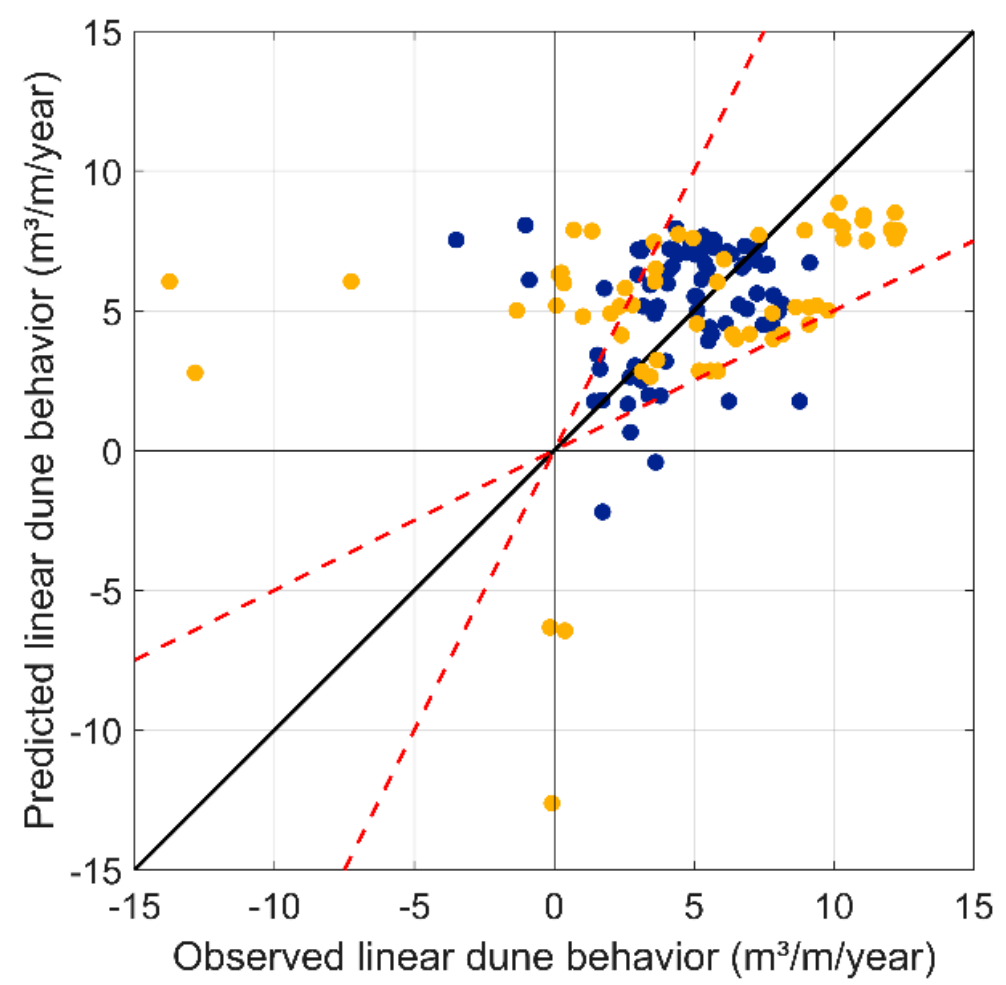

Figure 26. Comparison between observed and predicted linear dune development. Diagonal lines represent the one-to-one correspondence. Red dashed lines show the factor of two variance. Yellow dots represent the locations where managing activities are carried out.

Figure 27 shows the alongshore extent of the observed and predicted dune development rates along the Belgian coastline. The variability in potential transport is well correlated to the variability 
in dune volume changes at the considered spatial-temporal scale. The general variability, on a decadal timescale, between observed and predicted rates could be partly attributed to the management activities at certain sections along the coast. It is uncertain how many of the dune regions are managed. An attempt has been made to know which dune regions are managed. Based on historical images from Google Earth, approximately $50 \%$ of the coastal dunes are managed. Most of these activities include regular plantation of brushwood fences, especially where observed linear dune behavior is higher than the predicted values (under the line of perfect agreement). Other discrepancies include the ones discussed in Section 4.4.1. The locations including dune foot protection measures, dune foot reinforcements, and dune blowouts, are mostly the locations where predicted values are higher than the observed values. When the managed zones are excluded from the data set, the best fit line slope is approximately one, and the RMSE (Root Mean Square Error) value is $2.9 \mathrm{~m}^{3} / \mathrm{m} /$ year. Most $(90 \%)$ of the predicted data are within a factor of two of the measured values. This is a high score, given all variabilities and non-uniformities involved in aeolian processes (wind field, sand composition, bed relief, surface roughness). The finding of potentially stronger correlations compared to the literature (e.g., $[4,18]$ ) at the Belgian coast are most likely caused by the generally wider beaches (between $150 \mathrm{~m}$ and $400 \mathrm{~m}$ ). Keijsers et al. [18] also found stronger correlations between the time series of potential sediment transport and dune volume on wider beaches $(>200 \mathrm{~m})$ at the Dutch coast. This indicates that natural dune behavior can be predicted with a reasonable accuracy on decadal timescales, and it suggests that annual differences in forcing and transport limiting conditions (wind speed and surface conditions) only have a slight effect on the overall variability of dune volume trends.

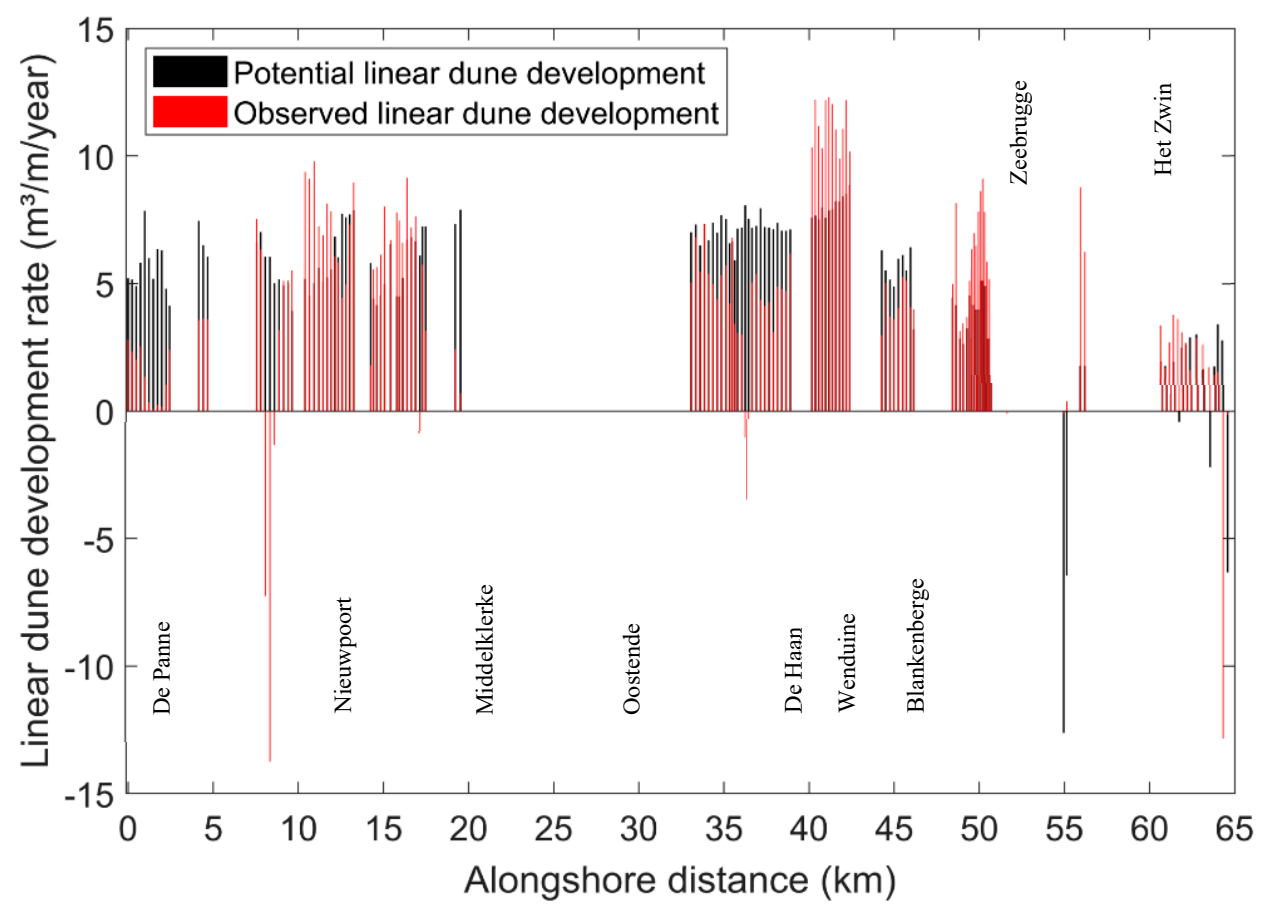

Figure 27. Annual predicted and observed dune volume change along the Belgian coast on a decadal timescale. Red and black bars indicate the observed and predicted values of dune development, respectively.

\section{Conclusions}

Long-term temporal and spatial dune trends along the Belgian coast are analyzed using a data set of annual and bi-annual beach-dune LiDAR surveys, conducted between 1979-2018. Furthermore, potential aeolian sediment transport along the Belgian coast is calculated on the basis of a wind data set from 2000-2017. On the basis of this analysis we conclude that: 
1. Along the Belgian coast, concerning the coastal sections with vegetated dunes (approximately half of the coast), it is found that the dunes grow at a constant rate. Linear regression analysis shows that $80 \%$ of the dune sections have linear correlations higher than 0.9 . There is alongshore variability in linear dune growth rates at the Belgian coast and they are found to be in the order of $0-12.3 \mathrm{~m}^{3} / \mathrm{m} /$ year. An average dune growth of $6.2 \mathrm{~m}^{3} / \mathrm{m} /$ year has been found.

2. Considering all coastal dune sections within the period of 2000-2017, onshore potential aeolian sediment transport ranges up to $9 \mathrm{~m}^{3} / \mathrm{m} /$ year (average $=5.2 \mathrm{~m}^{3} / \mathrm{m} /$ year), while longshore potential aeolian sediment transport could reach up to $20 \mathrm{~m}^{3} / \mathrm{m} /$ year (average $=18.7 \mathrm{~m}^{3} / \mathrm{m} /$ year). This means that total potential transport along the Belgian coastline is, on average, $20 \mathrm{~m}^{3} / \mathrm{m} /$ year. The main direction of aeolian sediment transport on the Belgian coast is from west to southwest. West to southwestern winds are oblique onshore to longshore with respect to the Belgian coastline. The larger parallel component (longshore) of the potential transport drift is directed towards the northeast (the Netherlands), while the normal component (onshore) is directed towards the southeast (hinterland).

3. There was no significant relationship between annual wind and dune volume change in the alongshore direction. However, a significant correlation is found between potential and observed dune volume development on a decadal timescale, indicating that dune growth is primarily caused by aeolian sediment transport from the beach. Most of the predicted data are within a factor of two of the measured values. The finding of potentially stronger correlations at the Belgian coast are most likely caused by the wider beaches (between $150 \mathrm{~m}$ and $400 \mathrm{~m}$ ) due to the massive sand nourishments to keep the sediment budgets along the Belgian coast positive. It also suggests that annual differences in forcing and transport limiting conditions (wind speed and surface conditions) only have a slight effect on the overall variability of dune volume trends.

Author Contributions: G.S. conceived the overall concept and approach of this study. G.S. lead the design and development of the methodology and calculated decadal dune trends and potential aeolian transport. R.H. calculated dune volume from the airborne surveys. G.S. prepared the original draft of the manuscript with input from all co-authors. R.H. and P.R. also contributed to the manuscript revisions and editing until the final version was created. P.R. supervised the entire study.

Funding: This publication was made possible through funding support of the KU Leuven Fund for Fair Open Access.

Acknowledgments: This publication is the result of research part of the project CREST (Climate REsilient coaST), funded by the Strategic Basic Research (SBO) program of the Flanders Innovation and Entrepreneurship. We thank the support of Coastal Division of the Flemish Government, Department of Mobility and Public Works, to make it possible to use the data of dune volume and wind.

Conflicts of Interest: The authors declare no conflict of interest. The founding sponsors had no role in the design of the study; in the collection, analyses, or interpretation of data; in the writing of the manuscript, or in the decision to publish the results.

\section{References}

1. Nickling, W.G.; Davidson-Arnott, R.G.D. Aeolian sediment transport on beaches and coastal sand dunes. In Proceedings of the Canadian Symposium on Coastal Sand Dunes, Guelph, ON, Canada, 12-14 September 1990; pp. 1-35.

2. Delgado-Fernandez, I.; Davidson-Arnott, R.G.D. Sediment Input to Foredunes Description and Frequency of Transport Events at Greenwich Dunes, PEI, Canada. J. Coast. Res. 2009, 1, 302-306.

3. Baas, A.C.W.; Sherman, D.J. Spatiotemporal Variability of Aeolian Sand Transport in a Coastal Dune Environment. J. Coast. Res. 2006, 22, 1198-1205. [CrossRef]

4. De Vries, S.; Southgate, H.N.; Kanning, W.; Ranasinghe, R. Dune behavior and aeolian transport on decadal timescales. Coast. Eng. 2012, 67, 41-53. [CrossRef]

5. Vellinga, P. Beach and dune erosion during storm surges. Coast. Eng. 1986, 6, 361-387. [CrossRef]

6. Steetzel, H.J. Cross-Shore Transport during Storm Surges. Ph.D. Thesis, TU Delft, Delft, The Netherlands, 1993. 
7. Van Rijn, L.C. Erosion of Coastal Dunes Due to Storms; Leovanrijn-Sediment: Blokzijl, The Netherlands, 2013; pp. 1-18.

8. Delgado-Fernandez, I. Meso-scale modelling of aeolian sediment input to coastal dunes. Geomorphology 2011, 130, 230-243. [CrossRef]

9. Strypsteen, G.; Montreuil, A.L.; Rauwoens, P. Aeolian sand transport at the Belgian coast: Field campaigns and fist results. In Proceedings of the Coastal Dynamics 2017, Helsingør, Denmark, 12-16 June 2017.

10. Sarre, R.D. Aeolian sand drift from the intertidal zone on a temperate beach: Potential and actual rates. Earth Surf. Process. Landf. 1989, 14, 247-258. [CrossRef]

11. Dingler, J.R.; Hsu, S.A.; Reiss, T.E. Theoretical and measured aeolian sand transport on a barrier island, Louisiana, USA. Sedimentology 1992, 39, 1031-1043. [CrossRef]

12. Jackson, N.L.; Nordstrom, K.F. Effects of time-dependent moisture content of surface sediments on aeolian transport rates across a beach, Wildwood, NJ, USA. Earth Surf. Process. Landf. 1997, 22, 611-621. [CrossRef]

13. Nordstrom, K.F. Offshore Aeolian Transport across a Beach: Carrick Frinn Strand, Ireland. J. Coast. Res. 1996, 12, 664-672.

14. Strypsteen, G.; van Rijn, L.C.; Rauwoens, P. On the relation between predicted and observed aeolian transport rates: A field study at the Belgian coast. Aeolian Res. 2019. under review.

15. Law, M.N.; Davidson-Arnott, R.G.D. Seasonal controls on aeolian processes on the beach and foredune. In Proceedings of the Canadian Symposium on Coastal Sand Dunes, Guelph, ON, Canada, 12-14 September 1990; pp. 49-68.

16. Pye, K.; Blott, S.J. Decadal-scale variation in dune erosion and accretion rates: An investigation of the significance of changing storm tide frequency and magnitude on the Sefton coast, UK. Geomorphology 2008, 102, 652-666. [CrossRef]

17. Brodie, K.; Conery, I.; Cohn, N.; Spore, N.; Palmsten, M. Spatial Variability of Coastal Foredune Evolution, Part A: Timescales of Months to Years. J. Mar. Sci. Eng. 2019, 7, 124. [CrossRef]

18. Keijsers, J.G.S.; Poortinga, A.; Riksen, M.J.P.M.; Maroulis, J. Spatio-temporal variability in accretion and erosion of coastal foredunes in the Netherlands: Regional climate and local topography. PLoS ONE 2014, 9, e91115. [CrossRef] [PubMed]

19. Bagnold, R.A. The Physics of Blown Sand and Desert Dunes, 2nd ed.; Methuen: London, UK, 1954; pp. 1-265.

20. Kadib, A.A. A Function for Sand Movement by Wind; FAO: Rome, Italy, 1965; pp. 1-103.

21. Hsu, S.A. Computing Eolian sand transport from routine weather data. In Proceedings of the 14th International Conference on Coastal Engineering, Copenhagen, Denmark, 24-28 June 1974; pp. 1619-1626.

22. McKee, E. A Study of Global Sand Seas; US Government Printing Office: Washington, DC, USA, 1979; pp. 1-439.

23. Kroon, A.; Hoekstra, P. Eolian Sediment Transport on a Natural Beach. J. Coast. Res. 1990, 6, 367-379.

24. Vandebroek, E.; Dan, S.; Vanlede, J.; Verwaest, T.; Mostaert, F. Sediment Budget for the Belgian Coast: Final Report; Antwerp \& Antea Group: Antwerpen, Belgium, 2017; pp. 1-105.

25. Charlier, R.H.; De Meyer, C.P. New Developments on Coastal Protection along the Belgian Coast. J. Coast. Res. 1995, 11, 1287-1293.

26. Lebbe, L.; Van Meir, N.; Viaene, P. Potential Implications of Sea-Level Rise for Belgium. J. Coast. Res. 2008, 24, 358-366. [CrossRef]

27. Verwaest, T.; Vanpoucke, P.; Vanderkimpen, P.; Van der Biest, K.; Reyns, J.; Peeters, P.; Kellens, W.; Vanneuville, W.; Mostaert, F. Overstromingsrisico's aan de Vlaamse Kust. Evaluatie van de Zeewering: Deel 1. Methodologie; WL Rapporten, 718_2A; Waterbouwkundig Laboratorium/Universiteit Gent/Soresma/Haecon: Antwerpen, Belgium, 2008; pp. 1-225.

28. Haerens, P.; Bolle, A.; Trouw, K.; Houthuys, R. Definition of storm thresholds for significant morphological change of the sandy beaches along the Belgian coastline. Geomorphology 2012, 143-144, 104-117. [CrossRef]

29. International Marine \& Dredging Consultants (IMDC). DO4: Morfologische Evolutie van de Vlaamse Kust Ingedeeld in Morfologisch Homogene Kuststroken, vanaf de Eerste Meetvlucht tot 2009; Rekening Houdend Met de Aangevoerde Zandhoeveelheden: Oostende, Belgium, 2010; pp. 1-86.

30. Houthuys, R. Morfologie van de Vlaamse Kust in 2011, Agentschap Maritieme Diensverlening en Kust; Afdeling Kust: Oostende, Belgium, 2012; pp. 1-150.

31. Deronde, B.; Houthuys, R.; Henriet, J.P.; Van Lancker, V. Monitoring of the sediment dynamics along a sandy shoreline by means of airborne hyperspectral remote sensing and LIDAR: A case study in Belgium. Earth Surf. Process. Landf. 2009, 34, 155-161. [CrossRef] 
32. Revell, D.L.; Komar, P.D.; Sallenger, A.H. An application of LIDAR to analyses of El Niño erosion in the Netarts littoral cell, Oregon. J. Coast. Res. 2002, 18, 792-801.

33. Sallenger, A.H., Jr.; Krabill, W.B.; Swift, R.N.; Brock, J.; List, J.; Hansen, M.; Holman, R.A.; Manizade, S.; Sontag, J.; Meredith, A.; et al. Evaluation of airborne topographic LIDAR for quantifying beach changes. J. Coast. Res. 2003, 19, 125-133.

34. White, S.A.; Wang, Y. Utilizing DEMs derived from LIDAR data to analyze morphologic change in the North Carolina coastline. Remote Sens. Environ. 2003, 85, 39-47. [CrossRef]

35. Stockdon, H.; Sallenger, A.; List, J.; Holman, R. Estimation of shoreline position and change using airborne topographic LIDAR data. J. Coast. Res. 2002, 18, 502-513.

36. Delgado-Fernandez, I.; Davidson-Arnott, R.G.D. Meso-scale aeolian sediment input to coastal dunes: The nature of aeolian transport events. Geomorphology 2011, 126, 217-232. [CrossRef]

37. Arens, S.M. Transport rates and volume changes in a coastal foredune on a Dutch Wadden island. J. Coast. Conserv. 1997, 3, 49-56. [CrossRef]

38. Van Rijn, L.C. Aeolian Transport over a Flat Sediment Surface; Leovanrijn-Sediment: Blokzijl, The Netherlands, 2018; pp. 1-33.

39. Sherman, D.J.; Li, B. Predicting aeolian sand transport rates: A reevaluation of models. Aeolian Res. 2012, 3 , 371-378. [CrossRef]

40. Valance, A.; Rasmussen, K.R.; Ould El Moctar, A.; Dupont, P. The physics of Aeolian sand transport. Comptes Rendus Phys. 2015, 16, 105-117. [CrossRef]

41. Davidson-Arnott, R.G.D.; Law, M.N. Measurement and Prediction of Long-Term Sediment Supply to Coastal Foredunes. J. Coast. Res. 1996, 12, 654-663.

42. Lynch, K.; Jackson, D.W.T.; Cooper, J.A.G. Aeolian fetch distance and secondary airflow effects: The influence of micro-scale variables on meso-scale foredune development. Earth Surf. Process. Landf. 2007, 33, 991-1005. [CrossRef]

43. Delgado-Fernandez, I. A review of the application of the fetch effect to modelling sand supply to coastal foredunes. Aeolian Res. 2010, 2, 61-70. [CrossRef]

44. Spies, P.J.; McEwan, I.K. Equilibration of saltation. Earth Surf. Process. Landf. 2000, 25, 437-453. [CrossRef]

45. Van Rijn, L.C.; Walstra, D.J.R. Modelling of Sand Transport in DELFT3D; Deltares: Delft, The Netherlands, 2003; pp. 1-154.

46. Ruz, M.H.; Anthony, E.J. Sand trapping by brushwood fences on a beach-foredune contact: The primacy of the local sediment budget. Z. Geomorphol. Suppl. Issues 2008, 52, 179-194. [CrossRef] 